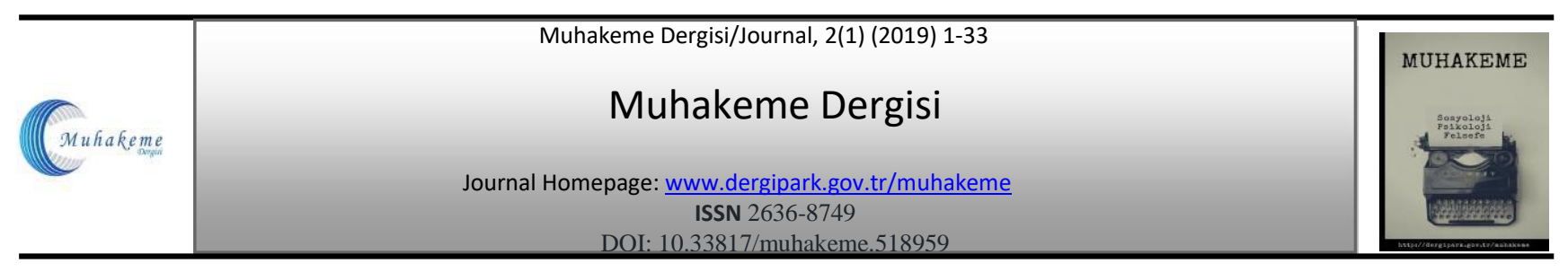

\title{
Kadın Akademisyenlerin Kadına Yönelik Ekonomik Şiddet Algısı: Düzce Üniversitesi Örneği
}

\author{
Gülden KILIÇ⿻1
}

\section{ÖZET}

Kadına yönelik şiddetin çeşitli türleri ile mücadele edebilmek için izlenmesi gereken öncelikli yol şiddetin görünür hale gelmesidir. Karşı karşıya kalınan şiddet türünün kavramsal içeriğinin doldurulması gerekmektedir. Farklı unsurlar göz önünde bulundurulduğunda belirtilen hususların, toplumsal yapıda aktör olan ve daha çok üst tabakaya yakın olan akademisyen kadınlar tarafından nasıl anlamlandırıldığı sorusu akla gelmektedir.

$\mathrm{Bu}$ açıdan yaptığımız çalışmada, kadın akademisyenlerin gözünden genel olarak kadının toplumdaki yerini, kadına yönelik şiddeti ve özel olarak kadına yönelik ekonomik şiddeti nasıl anlamlandırdıkları analiz edilmeye çalışılmıştır. Nitel araştırma yöntemiyle 7 evli ve 7 bekâr kadın akademisyenle yapılan görüşmelerde çarpıcı sonuçlara ulaşılmış, kadına yönelik ekonomik şiddet ve diğer şiddet türlerinin azaltılmasında kadının ne kadar önemli fonksiyonlarının olduğu ortaya konulmuştur.

Anahtar kelimeler: ekonomik şiddet, kadın, kadın akademisyen, şiddet, toplum

\section{Female Academics' Perceptions of Economic Violence Towards Woman: The Case of Düzce University}

\section{ABSTRACT}

To be able to contend with the various kinds of the violence against women, primary path that should be followed is making the violence apparent. The conceptual content of the kind of violence being faced must be cleared up. When the various parameters are taken into considerations, the question of how the given matters are being interpreted by the academic women who are actors in societal structure and mostly closer to the upper strata comes to mind. In this study we conducted by this perspective, from the eyes of the women academics, how they interpret the woman's position in the society, the violence against women and specifically the economic violence towards woman are tried to be evaluated. By qualitative research methods, in the interviews conducted with 7 married and 7 single women striking results have been deduced; how important functions that the woman has in the attenuation of the economic violence against women and other violence types have been revealed.

Keywords: economic violence, woman, female academic, violence, society

\section{GíRIŞ}

Toplumsal yaşamda her geçen gün şiddet olgusunun çeşitlenerek arttığını söylemek mümkündür. Gündelik yaşamın her alanında karşımıza çıkan şiddetin çeşitlerinden olan kadına yönelik şiddetin günümüzde arttığını belirtmek pekte yanlış olmaz. Çünkü son dönemlerde medyada çıkan haberlerde eskiye göre, yoğunlukla kadına karşı şiddetle karşılaşılmaktadır. Esasında burada sorulması gereken soru kadına yönelik şiddet olaylarının artması mı? Yoksa geçmişte de var olan bu şiddetin görünürlüğünün gün yüzüne çıkması mıdır? Toplumsal cinsiyet bağlamında aile içi ilişkilerde değişme söz konusu olduğu taktirde, değer yargılarında değişme durumunun görünürlüğü artmaktadır. $\mathrm{Bu}$

\footnotetext{
${ }^{1}$ Öğrt. Gör., Düzce Üniversitesi, Kaynaşlı Meslek Yüksekokulu, Acil Durum ve Afet Yönetimi Programı, guldensener@ duzce.edu.tr

- Bu çalışma 2017 yılında Cumhuriyet Üniversitesi Sosyal Bilimleri Enstitüsü'nde kabul edilen "Kadın Akademisyenlerin KadınaYönelik Ekonomik Şiddet Algısı: Düzce Üniversitesi Örneği” adlı yayımlanmamış Yüksek lisans tezinden üretilmiştir.
} 
görünürlüğün artmasında kuşkusuz kadının bilinçlilik seviyesinde yükselmenin, eğitim seviyesinin, gündelik yaşam pratiklerinin değişiminin ve medya gibi unsurların büyük etkisi bulunmaktadır.

Belirtilen bu gibi unsurlar kadına yönelik şiddetin çeşitliliğini ortaya koyup, görünürlüğünü arttırsa da bilindiği gibi şiddet türleri, birbirini doğuran ve besleyen yapıdadır. Şiddet türlerinin birbirine eşlik ettiği ve pek çok vakada birkaç şiddet türünün bir arada yaşandığı yapılan çalışmalarda açıkça gözükmektedir. Toplumda fiziksel ve cinsel şiddet direkt olarak görülebilen ve aile içerisinde kadına ve çocuğa karşı en çok uygulanan şiddet türlerindendir. Somut olarak gözlenebilen bu şiddet türlerinin toplumsal algıda ön plana çıkması diğer şiddet türlerinin göz ardı edilmesine imkân vermemelidir. Kadınların birçoğunun günümüzde tam olarak anlamlandıramadığı, bilim dünyasında da yakın zamanlarda kendisine çalışma alanı bulan ekonomik şiddet olgusu belki de diğer şiddet türlerine göre çok daha yüksek seviyededir.

Daha çok dolaylı olarak varlığını hissettiren psikolojik etmenlerle birlikte ele alınan ekonomik şiddet bir erkek suiistimali olarak görülmekte, kadınların ihtiyaçlarını karşılamak için para bağımlılığını ortaya koymaktadır (Kocadaş ve Kılıç, 2012: 351). Bu durumun daha çok düşük sosyo-ekonomik yapıdaki ailelerde gözlendiğini (Köse ve Beşer 2007: 116) ve kadın yaşamını bağımlı hale getirip sınırlandırdığını söyleyebiliriz.

Kadın yaşamını önemli oranda etkileyen, kadını bağımlı ve fakir hale getiren ekonomik şiddet dar kapsamda; eşin para vermemesi, harcamaları sınırlaması, kadının gelirine el koyması, zorla çalıștırılması ya da çalıșmasına izin vermemesi biçiminde tanımlanabilir. Ekonomik şiddet örneklerini çoğaltan bir başka tanımlama ise; kadının çalışma hayatına katılmasının, gelir elde etmesinin, kocası, evlâtları, akrabaları tarafindan engellenebilmesi ya da tam tersine istemediği bir işte çalışmaya zorlanması, kazandığı paranın elinden alınması, ailenin geçiminin sağlanmasının kadına yüklenebilmesi, mirastan ve mülkiyetten eşit hak elde edememesi ve aşırı veya düşük ücretle ya da sözleşme dışındaki koşullarda çalıştırılmaması, erkeklerle aynı ücreti almamasıdır (Eşkinat,2013: 292). Tanımlardan da anlaşılacağı üzere kadını ikinci sınıf bir vatandaş statüsüne iten, kadının kişiliğini yok sayan ekonomik şiddet, kadınların karşı karşıya olduğu şiddetlerden en etkilisidir. İçinde bulunduğu ruh ve beden sağlığını olumsuz etkileyen koşullara karşı çıkma gücü ekonomik bağımsızlıkla doğrudan ilgilidir. Ekonomik bağımlılık kadının diğer şiddet türlerine uğrama konusundaki en zayıf noktasıdır (Eşkinat, 2012: 333). Kadına yönelik ekonomik şiddet daha çocukken büyüdügü ailede başlamakta, evlendiğinde ve/veya boşandığında devam etmektedir. Bu şiddetin temelinde bireysel faktörler ve toplum yapısındaki kültürel öğeler sayılabileceği gibi devletin uygulamalarındaki eksikliklerde önemli yer tutmaktadır (Adaçay ve Güney, 2012: 312).

Kadınların karar verme süreçlerinde erkeklerle eşit derecede yer alması, kadınların toplum içerisindeki statüsünün yükseltilmesi açısından oldukça önemli bir önkoşul olarak karşımıza çıkmaktadır. Akademik camia bu anlamda Türkiye'de cinsiyet ayrımcılığının daha az olduğu ve kadınların da erkeklerle benzer düzeyde iş gücüne katılabildiği bir alan olarak görülmektedir (Özdemir ve Tanyıldız, 2011: 1). Bilimsel işgücü içerisinde kadınların payı erkeklere kıyasla Türkiye'de daha az olsa da, gelişmiş ülkeler de dâhil olmak üzere birçok ülkenin benzer sorunlarla karşı karşıya olduğu ifade edilebilir (Hill, Corbett and Rose, 2010: 2).

Kadın akademisyenlerin kadının toplumsal yaşamdaki rolü ve kadına yönelik şiddetin toplumsal anlamları üzerine bakış açıları, kadının toplumsal pozisyonunun yeniden inşasında önemlidir. $\mathrm{Bu}$ açıdan kadına yönelik şiddetin arkasında yatan unsurları gün yüzüne çıkarmak ve günümüzde toplumsal yaşamda kadınlar tarafindan da yeterince anlamlandırılamayan ekonomik şiddetin, topluma yol gösterici olarak görülen bilim insanları (özelde kadın akademisyenler) açısından ne anlam ifade ettiği ve onların gözünden nasıl politikalar oluşturulması gerektiği sorgulanmaktadır.

Çalışmanın amacı ve önemine bağlı olarak, kadına yönelik şiddetin çeşitleri, kadının iş hayatına katılımı kuramsal bakış açıları ekseninde incelenmiştir. İkinci olarak, yöntemde belirtilen bütün hususlara bağlı olarak, Düzce Üniversitesi kadın akademisyenleri üzerine yapılan nitel araştırmanın bulguları literatür bağlamında temalar başlıkları altında analiz edilmiştir. Son olarak, değerlendirme ve sonuç kısmına yine bu bölümde yer verilmiş ve araştırma bulguları sistematik olarak tartışılmıştır. 


\section{Kadına Yönelik Şiddet}

\section{Fiziksel Şiddet}

Fiziksel şiddet toplumsal yaşamda şiddetin en sık ve görünür şekli olarak karşımıza çıkmaktadır. Fiziksel şiddet daha çok bedene yöneliktir ve bedensel güce dayalıdır. Bu şiddet türünün, hafif yaralanmalara neden olan eylemlerden cinayete kadar geniş bir yelpazede gerçekleşebildiği görülmektedir. Yumruk-tokat atmak, tekmelemek, itip kakmak, kadının üstünde sigara söndürmek, kesici-delici aletle yaralamak gibi (Şener, 2011: 12) bedene karş1 zarar vermek için ortaya konulan eylemsel davranışın tümü fiziksel şiddete örnek olarak verilebilir.

Kadına karşı uygulanan fiziksel şiddetin temelinde bir güç göstergesi ve kontrol etme mekanizması yatmaktadır (Fraim, 2012: 1). Çetin'e (2012: 7) göre, bu durum erkek ve kadın arasındaki tarihsel olarak eşitliğe dayanmayan güç ilişkilerinin bir göstergesidir. Erkekler bu iki cinsiyet arasındaki eşitsizlikten cesaret alarak kadınlar üzerinde hâkimiyet kurmuşlar, onlara karşı ayrımcılık uygulamışlar ve onların gerçek anlamda ilerlemesini önlemeye çalışmışlardır. Çetin'in söyleminden hareketle toplumda son yıllarda kadınlara karşı ciddi boyutlarda uygulanan şiddetin temelinde gelenekselliğin ve modernliğin aynı anda yaşanıyor olmasının yarattığı çelişkiler olduğu iddia edilebilir. Bu toplumda erkek halen geleneksel rolünü idame ettirmeye çalışmakta ve halen geleneksel kodlara göre hareket etmektedir.

Fiziksel şiddetin neden olduğu fiziksel ve fizyolojik sonuçları değerlendirdiğimiz zaman şiddetin boyutuna baktığımızda bazen geriye dönüşü olmayan kalıcı sonuçlarla karşılaşmak söz konusudur. Fiziksel sonuçlar deride oluşan hematomlar (morluklar), ödemler, kesikler, yanıklar, bağlama izleri gibi gözle görülebilen sonuçlardan oluşmaktadır. Fizyolojik sonuçlar arasında da gözle görünmeyen nörolojik, jinekolojik, darbe sonucunda iç fizyolojiye zarar veren ve geriye dönüşü kalıcı hasarlardan oluşmaktadır. Örneğin, fiziksel şiddet mağduru olan bir kadının eşi kafasına bir cisimle vurduğunda öncelikle darbe sonucunda bir şişlik, olası deri yarılması ve kanama olabilir. Ancak daha ciddi boyutta mağdur olan kadın nörolojik sorunlar yaşayabilir. Sağlıklı bir kadınken bir anda bilişsel fonksiyonlarında kayıplar ve hasarlar oluşabilir. Bu örnek üzerinden fiziksel şiddet mağduru olan kadınlar yaşadıkları şiddet sonucunda doğrudan ve dolaylı yoldan sosyolojik sonuçlara da maruz kalmaktadırlar. Yapılan araştırmalarda, küçük toplumsal oluşumlarda ya da çok fazla gelişmemiş şehirlerde ve gelişmiş metropollerde yaşayan kadınları ele aldığımız zaman "hemşeri mahalleleri” gibi oluşumların getirmiş olduğu bazı olgular arasında kimse duymasın, görmesin, el-âlem ne der, ele güne rezil olmak gibi düşüncelerin (Fraim, 2012: 3) etkisiyle gün yüzüne fiziksel şiddetin çıkartılmadığı görülmektedir. Birçok şiddet türünün birlikte gerçekleştiği savındaki gibi, fiziksel şiddet de çoğu durumda tek başına gerçekleşmemektedir. Diğer şiddet türleri de fiziksel şiddete eşlik etmektedir. Kuşkusuz psikolojik şiddet bu şiddet türlerinin başını çekmektedir.

\section{Psikolojik Şiddet}

Kadına yönelik psikolojik şiddet; kadına bağırmak, hakaret etmek, onu aşağılamak, başka kadınlarla kıyaslamak, kıskanmak, nasıl giyineceğine, nereye gideceğine, kimlerle görüşeceğine karar vermek, ölüm ile tehdit etmek, onun diğer insanlarla ilişkilerini sınırlamak, kendini geliştirmesine engel olmak, yaşadığı şiddetin sorumlusu olarak görmek, kültürel farklılıklarını reddetmek, bastırmaya çalışmak veya bu gerekçeyle muamelede bulunulması gibi anti-demokratik ve insan haklarına aykırı süreçleri içeren uygulamalardır (Keskin, 2012: 92).

Psikolojik şiddet, fiziksel şiddetten bağımsız olarak gerçekleşse dahi her zaman fiziksel şiddete ya da diğer bir şiddete dönüşme tehlikesini içinde barındırmaktadır. En yaygın şiddet türlerinden olan psikolojik şiddet, kadının psikolojik bütünlügünü ağır şekilde ihlal etmektedir. Psikolojik şiddetin tehlikesi çoğu kez normalleştirilmesinde saklıdır. Çünkü çoğu durumda şiddetin bu türü meşrulaştırılmakta, bir suç, kişilik hakkına tecavüz olarak algılanmamaktadır. Bu şiddet türü aynı zamanda, kadının kendine olan inancını, kimliğini kaybetmesine yol açabilmektedir (Şener, 2011: 13). Dövüleceğinden korkan kadının psikolojik olarak da örselenebileceğini söylemek yanlış değildir. Erkeğin kadına evi terk ederse intihar edeceğini, çocuklarını kaçıracağını söylemesi kadın için bir korku kaynağı olabilir. Bazı durumlarda erkeğin, kadının geçmişiyle ilgili olumsuz şeyleri çevresine ya 
da kamuya açıklayacağını söylemesi de kadın için ciddi bir korku kaynağı olur ve kadını terk etmekten alı koyabilir (Aktaş, 2006: 35).

Kadına yönelik psikolojik şiddet sadece aile içerisinde değil özel ve kamusal alan içerisinde de sıkça rastlanmaktadır. İşyerinde psikolojik şiddeti ifade etmede yıldırma (mobbing), zorbalık (bullying), taciz (harrasment), duygusal istismar (emotional abuse), kötü davranma (mistreatment), psikolojik terör (psychological terror), günah keçiciliği (scapegoating), işyeri travması (workplace trauma) gibi pek çok farklı kavram kullanılmaktadır (Zapf, 1999: 167).

İşyerinde psikolojik şiddet özellikle son yıllarda yaygınlığı artan bir işyeri şiddeti biçimi olarak görülmektedir. İş yerinde 1980'lere kadar tanımlanmamış olan psikolojik şiddet, bir veya birkaç çalışan/işveren tarafindan sistematik biçimde, bir başka çalışına yöneltilen, sağlık ve güvenlik riski yaratan, sıklıkla ve uzun bir süre devam eden, hedef aldığı mağduru korunmasız ve çaresiz bir durumda bırakan düşmanca ve gayri ahlaki bir etkileşimi ifade etmektedir. Bu olguyu tanımlamak için birbirleri yerine geçen pek çok farklı kavram kullanılmış olsa da (yıldırma, zorbalık, duygusal taciz vb.), her birinin tanımladıkları süreç, nedenleri ve etkileri bakımından aynıdır. Ancak, çalışanlar arasında görülen düşmanca ve uygunsuz her davranışı psikolojik şiddet olarak da tanımlamak mümkün değildir. Bu tür düşmanca ve gayri ahlaki davranışların kasıtlı biçimde kurgulanmış sistematik bir süreç içinde gerçekleşmesi gerekmektedir (Özen, 2007: 21).

\section{Cinsel Şiddet}

Cinsel şiddet yakın döneme kadar fiziksel şiddetin bir uzantısı olarak ele alınmaktaydı. Bunun nedeni ise çoğunlukla somut olarak gözlenebilmesi ve fiziksel bir eyleme bağlı olarak gerçekleşmesinin göz önünde bulundurulmasıdır. Ama günümüzde cinsel şiddetin sadece fiziksel bir eylem olarak düşünülmesi söz konusu değildir. Bu açıdan psikolojik şiddetle de çok yakın ilişkinin kurulması söz konusudur. Kadının bir cinsel obje olarak görülmesi, gözle ya da sözle kadının taciz edilmesi gibi durumlarda cinsel şiddet olarak değerlendirilmektedir.

Fiziksel açıdan cinsel şiddet, kişinin isteği gözetilmeksizin cinselliğin bir zorlama ve kısıtlama aracı olarak kullanımıdır. Evlilik içi tecavüz, kadının fiziksel veya duygusal baskıyla cinselliğe zorlanması, kadının cinsellikte tamamen bir obje olarak kullanılması, ensest ve cinsel taciz bu șiddet türünün yansımalarıdır. Kadınlar üzerindeki araştırmalar göstermiştir ki; evlilik içindeki zorlamayla cinsel ilişkiye girme kadınlarca tecavüz olarak tanımlanmamaktadır. Ancak bu şekilde tanımlanmaması kadınlar üzerindeki etkilerinde bir farklılık yaratmamakta, yine kadınlar üzerinde yıkıcı psikolojik etkiler göstermektedir. Bu durum aile içinde de gözlenmektedir. Örneğin, Ankara' da kadınlar arasında, 155 kadınla yapılan bir araştırmada, kadınlardan \% 15'i en az bir kez eşleri tarafından cinsel birleşmeye zorlandıklarını söylemişlerdir (Mutlu, 2006: 30).

Cinsel şiddete teşebbüs eden erkekler gerçekte kadını bir partner olarak görmezler. Bu nedenle de kadının ihtiyacını ve doyumunu dikkate almazlar. Onlar için kadının bedeni cezalandırma objesidir. Bazen erkek pornografik dergi ve filmlerdeki yaşantıları eşiyle de yaşamak isteyebilir. Kadını hoşlanmadığı ilişkilere zorlayabilir. Kadın, kocasının istekleri karşısında kendi toleransının düşük olduğuna bile inanabilir. Bunun nedeni partnerinin cinsel ilişki isteğini reddetme özgürlüğüne sahip olduğunu bilmemektir. Çünkü eşiyle her istediğinde birlikte olması "kadınlık görevleri” arasında görülmektedir. Cinsel şiddet olayının büyük bir bölümü fiziksel şiddet ve öldürme ile sonuçlanabilir (Aktaş, 2006: 35).

Cinsel şiddetin sadece aile içerisinde ele alınmaması gereken bir konu olduğunu söylemekte fayda vardır. Sosyal yaşamda birbirleriyle birincil ilişkileri olmayan ya da birbirini tanımayan insanlar arasında da oldukça fazla yaşanan şiddet türüdür. Ne yazık ki Yeşilçam sinema filmlerde bile sıklıkla karşılaşılan ve trajikomik olarak sunulan cinsel şiddet sapkın kişilikte olan insanların bilinçaltına nüfuz etmekte ve bu tür vahşilikleri kendilerince meşrulaştırmaktadırlar. Mersin'de hunharca tecavüz edilen ve öldürülen üniversite öğrencisi Özgecan Aslan ya da küçük yaşta zihinsel engelli kız çocuklarına yönelik tecavüzler gibi birçok olay cinsel şiddetin ne kadar vahim derecede yaşandığını göstermektedir. 


\section{Ekonomik Şiddet}

Ekonomik şiddet; ekonomik kaynakların ve paranın kişiler üzerinde bir yaptırım, iktidar ve tehdit aracı olarak kullanılmasıdır. Ekonomik şiddete en fazla maruz kalanlar kadınlardır ve bu şiddet türünün tezahürleri maalesef çoğu zaman, kadınlar tarafından bir şiddet biçimi olarak algılanmamaktadır. Psikolojik ve/veya cinsel şiddetle iç içe yaşanıyor olması genellikle bu şiddet türünün şiddete uğrayan kadınlar tarafından fark edilmesini engellemektedir. Türkiye'de kadına yönelik şiddet üzerine yapılan araştırmalarda kadınların, diğer şiddet türlerine oranla, ekonomik şiddeti anlamlandıramadıkları görülmektedir.

Ekonomik şiddet "kadının çalışmasına izin vermeme, istemediği işte zorla çalıştırma, çalışıyorsa iş hayatını olumsuz etkileyecek kısıtlamalar getirme, sık sık işyerinde olay çıkartarak çeşitli bahanelerle işe girmesine engel olma, çalışma yaşamında ilerlemesine engel olma, maaşına, gelirine, mal varlıklarına el koyma, az para verme, para harcama özgürlügünü elinden alma, çok az para verip yapılması mümkün olmayan şeyleri talep etme, yiyecek/giyecek gibi ihtiyaçlarını almasına izin vermeme, sağlık hizmetlerinden yararlanmasını engelleme, ailenin tasarrufları, gelir ve giderleri konusunda bilgi vermeme, aileyi ilgilendiren ekonomik konularda kadının fikrini almadan tek başına karar verme, kadının ev ekonomisine katkısını kabul etmeme, ortak miras, mal-mülk konusunda ayrımcı davranışlar sergileme ve bu davranışları boşandıktan sonra da devam ettirme, çalışmayı reddedip, kadının gelirini harcama gibi durumları içerir (Xu at all. 2005: 79; Gürkan ve Coşar 2009: 120, 125; Eşkinat 2013: 329).

Kadın sadece ekonomik şiddete ailede maruz kalmamakta aynı zamanda devletin uygulamalarındaki eksikliklerden kaynaklı ekonomik şiddete de uğramaktadır. Aile içinde kadına yönelik şiddeti üreten dinamikler, yalnızca aile içinden değil toplumun toplumsal, hukuksal, ekonomik, siyasal ve eğitimsel yapısı içindeki ayırımcı ve kadını erkeğe bağımlı kılan mekanizmalardan kaynaklanmaktadır (Ekizceleroğlu ve Zeyrekli, 2007: 66-67).

Devletin uygulamalarındaki eksikliklerden kaynaklanan kadına yönelik ekonomik şiddet, işgücü piyasasındaki eşitsizlikler, eğitimdeki, siyasetteki, karar mekanizmalarındaki ayırımcılık ve eşitsizlikler, kadınları düşük gelirli işlere mahkûm bırakan, ekonomik güç elde etmesini engelleyici uygulamalardır. Kadının kendine ait sosyal güvenliğinin olmamasına yol açan uygulamalarla yaratılan 'sosyal güvencesizlik ve erkeğe bağımlılık' ekonomik şiddettir. Bu anlamda genel sağlık sigortasının yokluğu, vatandaşlık aylığının yokluğu, çocuk yardımı vb. bazı ödemelerin kadına verilmemesi gibi devlet uygulamaları da devletin kadına yönelik ekonomik şiddeti olarak değerlendirilebilir. Çalışan yoksulların önemli bir kısmını oluşturan örneğin ev eksenli çalışma gibi çalışma türlerinde çalışanlarla ilgilenmemek, onların işçilik haklarını ve sosyal güvenliklerini düzenlememek ekonomik şiddettir (Iş1k, 2007: 117).

Görüldüğü üzere kadınlar, hem evde ürettikleriyle hem de toplumsal yaşamın diğer alanlarında ürettikleriyle çalışma yaşamının en önemli ögesi olmalarına rağmen hâlâ ekonomik şiddete maruz kalmaktadirlar.

Konuyla ilgili yapılan çalışma örneklerine baktığımızda, Malatya ilinde 545 kadınla yapılan açıklayıcı alan araştırmasında "eşinizle kavga ediyorsanız en fazla neyden dolayı" sorusuna "tanışıp anlaşarak" evlenenlerin \%20,5 ve "görücü usulüyle" evlenenlerin \%17.1'i ekonomik sebeplerden olduğunu söylemiştir. Yine aynı araştırmada kadınların \%78 oranında ev hanımı olması ve ailelerin çoğunluğunun düşük sosyo-ekonomik yapıda olması sebebiyle kocadan görülen her türlü şiddete çocukları için katlanabileceklerini çok yüksek oranda kabul ettikleri tespit edilmiştir. Araştırma sonuçlarında kadınların hayatlarını idame etme noktasında eğitim ve mesleğinin olmamasının, ister istemez kendilerini kocalarına bağımlı hale getirdiği tespit edilmiştir (Kocadaş ve Kılıç, 2012: 357 358).

Sivas ilinde yapılan bir araştırmanın sonuçlarına göre ise kadınların \%40,7'si aile içi şiddete maruz kaldıklarını, bunların \%91'i eşi, \%19,7'si eşinin yakınları tarafından kendilerine şiddet uygulandığını belirtmiştir. Çalışmaya katılan kadınların büyük bir bölümünün (\%59.7) şiddeti fiziksel şiddet olarak tanımladıkları, ekonomik ve cinsel şiddeti tanımlayanların olmadığı görülmektedir (Güler ve ark., 2005: 51-56).

Türkiye'de kadınlar ev işlerine benzeyen hizmet sektöründe, sağlık, eğitim, tekstil, gıda gibi alanlarda çalışırlar. Ücretleri erkeklerinkinden düşüktür. Ekonomik kriz dönemlerinde öncelikle işten çıkarılırlar. Karar alıcı, yönetici, örgütleyici konumlara çok az sayıda ve çok zor gelebilirler. Evlilik ve çocuk gibi 
nedenlerle işi aksatma ve bırakma olasılıkları yüksektir. İşe alımlarda erkeklere öncelik verilir (Duruoğlu 2007: 63).

Kadınların iş gücüne katılımı kentlerde Türkiye ortalamasının altında, kentlerdeki kadın işsizlik oranı erkeklerin iki katıdır. En çok tarım alanında çalışan kadınların eğitim düzeyleri yükseldikçe işgücüne katılım oranları artmaktadır. Kadınlar çok iyi bir eğitime sahip olsalar da kazançları özel sektörde ancak erkeklerin \% 68'i, kamu sektöründe \% 76'sı oranındadır. Erkeklerin \% 54,5'ü ücretli çalışırken, kadınlar da bu oran \% 24.3'dür. Erkeklerin sadece \% 13.8'i ücretsiz aile işçisi konumundayken kadınlarda bu oran \% 68.8'dir. Çalışan her bin kadından ancak 9'u işveren pozisyonundadır (Duruoğlu, 2007: 73-74).

Belirtilen bu çalışmalardan hareketle geleneksel aile yapılarının, eğitim seviyesinin, ekonomik özgürlüğün ve daha önemlisi özgüven eksikliğinin kadının ekonomik şiddete ve diğer şiddet türlerine maruz kalmasında öncelikli faktörler olarak karşımıza çıkmaktadır. Elbette bu durumlar tek başına etken olarak ele alınmamalıdır. Kültürel sermayemizde erkeğin kadına biçtiği pozisyon ve atfettiği değer de oldukça önemlidir. Bu değerin verilmesini sağlayacak olan yani her erkeği büyüten ve topluma hazırlayanın bir anne/kadın olduğu düşünülürse, kadının toplumsal yaşamı anlamlandırması ve şiddetin her çeşidiyle mücadele etmesi gereklidir.

\section{Kadına Yönelik Şiddetle İlgili Teoriler}

Günümüzde cinsiyet ve toplumsal cinsiyet kavramları sıklıkla kullanılmaktadır. Bu kavramların birbirlerinin yerine kullanılması mümkün olmakta; fakat mümkün olması doğru olduğu anlamını taşımamaktadır. Cinsiyet, bireylerin anne karnında iken belirlenen, biyolojik, fizyolojik ve genetik olarak birbirlerinden ayrılmalarında belirleyici olan bir yapı özelliği anlamına gelmektedir (Acker, 1992: 565).

Toplumsal cinsiyet kavramı ile sadece biyolojik olarak kadın ve erkeğin birbirinden farklı olduğu değil, aynı zamanda bu farka dayalı olarak sosyal ve kültürel birtakım değerler konusundaki farklılıklar da vurgulanmaktadır. Böylece cinsiyet esas alınarak oluşturulan kategorizasyon sonucunda, bu kategorilere ilişkin davranış dizileri, kişilik özellikleri, sosyal roller meydana gelmektedir (Nicholson, 1994: 79-80).

Toplumsal cinsiyet eşitsizliği konusunda geliştirilen başlıca kuramlar sıralanacak olursa bunlar; sosyal öğrenme kuramı, bilişsel gelişim kuramı ve toplumsal cinsiyet şeması kuramlarıdır.

\section{Sosyal Ö̆̆renme Kuramı}

Sosyal Öğrenme Kuramı, bireyin öğrendiği bir davranışı gözle görülür bir şekilde gerçekleştirmeyebileceği, arkasından pekiştireç sunulmadığı zamanda öğrenmenin gerçekleşebileceği, insanın salt uyarıcılara karşı verdiği basit tepkilerle ele alınamayacak kadar karmaşık bir varlık olması sebebiyle davranışçılığa tepki olarak geliştirilmiş bir kuramdır. Bandura tarafından geliştirilen kuramda çocukların başkalarının saldırgan davranışlarını kolaylıkla taklit edebileceklerini göstermek için çeşitli deneysel ortamlar kullanılmıştır. Özellikle yetişkinler güçlü bir model oluşturmaktadırlar; zira çocuklar ebeveynlerini sorumlu ve güvenilir figürler olarak algılarlar (Kılıç, 2016: 23). Kuram özellikle temsili, sembolik ve öz-düzenleyici süreçlerin öğrenmede oynadığı role dikkat çekmektedir. Kurama göre öğrenme, pekiştirme ve model alma yoluyla gerçekleşmektedir. Çocuğa cinsiyet rolleri, günlük hayatta maruz kaldığı cinsiyete özgü stereotipler ve toplumda belirgin olan normlar ile empoze edilmektedir. Çocuk ebeveynleri tarafından kendi cinsiyetine özgü bir davranış yaptığında ödüllendirilmekte ve cinsiyete uygun davranmasının 'iyi' olduğu öğretilmektedir (Bandura 1978: 12-13). Gözleyerek öğrenirken kritik öğrenme kaynağı diğer insanlar olmaktadır ve öğrenmenin gerçekleşmesi için pekiştireç şart değildir (Taylor at all, 2007: 12). Küçük erkek çocuğu, kendi cinsiyetinden birinin erkeksi davranışlarda bulunduğu zaman desteklendiğini gözlediğinde de öğrenme gerçekleşebilmektedir.

\section{Bilişsel Gelişim Kuramı}

Bilişsel Gelişim Kuramı, çocuğun kendi gelişiminde aktif olanın yine kendisi olduğu görüşünü savunmaktadır. Bilişsel gelişimin temel düşüncesini organizmanın çevreye uyum yeteneği oluşturur. 
Bilişsel gelişimde çevreye uyum sağlayabilmek için denge, dengesizlik ve yeniden denge süreçlerinin sağlanması gereklidir. Çocuğun aktifliği ve içsel motivasyonu çok önemlidir. Bu hususlar cinsiyet gelişiminin oluşmasında kaynak teşkil eder. Kohlberg (1966) çocuklarda cinsiyet gelişiminin birbirini takip eden üç adım sonucunda oluştuğunu ileri sürmektedir. Bu adımlar cinsiyeti etiketlendirme, cinsiyetin değişmezliği ve cinsiyetin sürekliliğidir. Süreç basitten karmaşığa doğru ilerlemektedir ve çocuk içinde bulunduğu aşamaya göre davranış örüntüleri sergilemektedir (Cinsiyete özgü oyunlar oynama, kendi cinsiyetinden olan bireyleri gözleme vb.). Çocuklar kaçınılmaz olarak kendilerine bir etiket belirlemekte ve diğer insanları da kendi cinsiyetindekiler ve karşı cinsiyettekiler olarak ikiye ayırmaktadır. Çocuğun kendini kategorize etmesi ve söz konusu kategoriye uygun davranışlar öğrenip sergilemesi ise bilişsel çelişkiyi azaltmak içindir. Bu süreç zihinsel olarak sağlıklı bireylerde bilişsel gelişimin evrenselliğine bağlı olarak kaçınılmaz bir şekilde gerçekleşmektedir (Bem, 1983: 599).

\section{Toplumsal Cinsiyet Şeması Kuramı}

Toplumsal Cinsiyet Şeması Kuramı, Sandra Bem tarafından sosyal öğrenme kuramı ve bilişsel gelişim kuramı temel alınarak geliştirilmiş bir kuramdır. Bu kurama göre çocuklar cinsel kimliklerini oluşturmaya başladıkları zaman kendi cinsiyetlerine özgü olan beklenti ve kalıp yargıları öğrenmeye ve buna göre hareket etmeye başlarlar. Kuramın bu sayıltısı sosyal öğrenme kuramını hatırlatmaktadır. Cinsel kimliğini keşfeden ve buna özgü davranışları öğrenmeye başlayan çocuklar yavaş yavaş erkeksi ve kadınsı davranışları ayırt etmeye, bunları analiz etmeye ve örgütleyerek yeni şemalar oluşturmaya başlarlar. $\mathrm{Bu}$ kısım ise temellerini bilişsel gelişim kuramından almıştır. Oluşturulan şemalar doğrultusunda çocuk kendi davranışlarını biçimlendirmeye ve cinsiyetine uygun davranmaya başlamaktadır. Sonuç olarak hem şemalar oluşturulmuş hem de birey kendi davranışlarını bu şemalara göre şekillendirmiş olmakta ve süreç tamamlanmaktadır (Bem, 1983: 600-601). Toplumsal cinsiyet eşitsizliğinin nasıl öğrenildiği ve yaşama aktarıldığı konusunda en detaylı açıklamayı yapması sebebiyle en güçlü kuramın toplumsal cinsiyet şeması kuramı olduğu düşünülmektedir.

Özellikle Türkiye gibi ataerkil toplumlarda cinsiyete dayalı kalıp yargıların günlük yaşama yansıması oldukça sık rastlanan bir durumdur. Çocuklar doğdukları andan itibaren ilk olarak ebeveynleri tarafından daha sonrasında ise diğer akrabaları, öğretmenleri ve diğer bireyler tarafından cinsiyetlerine göre davranması gerektiği konusunda görünmez bir baskıya maruz kalmaktadırlar. Sosyal öğrenme kuramı ve bilişsel gelişim kuramı temel alınarak geliştirilen toplumsal cinsiyet şeması kuramında açıklandığı üzere çocuk kendi cinsiyetini fark etmekte, cinsiyetlere özgü davranış kalıplarını gözlemlemekte, bunlara ilişkin şemalar oluşturmakta ve bu şemalarla uyumlu olacak şekilde hareket etmeye başlamaktadır. Cinsiyete bağlı olarak insanların birbirinden ayrılması ise bir kutuplaşmayla; özellikle ataerkil toplumlarda erkeklerin yüceltildiği, kadınlara karşı ise ayrımcılık uygulamalarının yapılmasıyla sonuçlanmaktadır.

Toplumsal cinsiyete dayalı eşitsizliği ortaya koyan kuramlardan sonra kadınların işgücü sermayesinde yer edinmesiyle ilgili kuramlara baktığımızda; ikili rol kuramı, insan sermayesi kuramı, cinsiyetçi rol toplumsallaşması kuramı ve feminist kuram başta olmak üzere birçok kuram geliștirilmiștir. Toplumsal cinsiyet rollerine ilişkin açıklamalara dayandırılarak kadın ve erkeklere farklı rollerin atfedilmesi, kadınların daha çok ev içi faaliyetlerle ilgilenmesi, erkeklerin işgücü piyasasında daha çok firsata sahip olması ve daha fazla kazanç getiren işlerde çalışması gerektiğine dair kalıp yargıların var olması, kadınların çalışma hayatına girmesi ile birlikte birtakım açıklamalar geliştirilmesi gerekliliğini beraberinde getirmiştir. $\mathrm{Bu}$ sebeple kadınların işgücüne katılımı ile ilgili geliştirilen kuramların temelinde de yine toplumsal cinsiyet algısı bulunmaktadır. Bu kuramların açıklamaları da aşağıda verilmiştir.

\section{İkili Rol Kuramı}

İkili rol kuramı, kadınların istihdama katılmaları ve ücretli işçi tanımıyla işgücü piyasasında yer alması durumunu açıklamak üzere geliştirilmiş ilk kuram olma özelliği taşımaktadır (Ciner, 2003: 24). Kadının ev dışında çalışmasıyla birlikte ailedeki rolünün yanında iş yaşamında da bir rol üstlenmesi söz konusu olmuştur. Kuram bu iki rolün aileye zarar vermeden nasıl bağdaştırılacağı sorusuna yanıt aramak üzere ortaya çıkmıştır. Bu yaklaşım, öncelikle toplumsal cinsiyete bağlı olarak kadın ve 
erkeğin rollerini tanımlamasıyla da kadının hem işte hem evde erkeğe tabi olmasını önemsememekte ve bunu normal olarak değerlendirmektedir (Ciner, 2003: 26).

$\mathrm{Bu}$ kuram kadının öncelikli ve tercihen tek işinin evine bakmak olması gerektiğini, bunun yerine işgücü piyasasında yer edinerek maddi kazanç sağlamanın ikinci önceliği olması gerektiğini savunması açısından ataerkil bir yaklaşım olma özelliği taşımaktadır. Bu açıdan kadının ailedeki rolü ile iş yaşamındaki rolünün nasıl bağdaştırılacağı sorusuna yanıt arayan kuramda üretilen çözüm önerileri kadının yükünü daha da arttırmaktadır. Yine erkek egemen işyeri, kadına geçici gözle baktığı için ona yatırım yapmak yerine erkeğe yatırım yapmayı tercih etmektedir. Ayrıca ikili rol kuramı, kadınların neden daha az ücretle çalışmaya razı olduğunu da açıklamaktadır. Çalışan bazı kadınların amacı çocuğuna yetecek kadar para kazanmaktır ve aklı evindedir. Bu nedenle kadın bir erkek meslektaşının sahip olduğu ücret beklentisini taşımamaktadır. Aksine, onların çok daha altında ücretle çalışmayı kabul etmeye hazırdir (Uygun, 2011: 45-46).

\section{Insan Sermayesi Kuramı}

İnsan Sermayesi Kuramı, işgücünün ve sergilenen performansın heterojen olduğu varsayımı ile geliştirilmiş; iş görenin sahip olduğu yeteneklere ve verimliliğe göre farklı ücret dağılımının yapılması gerektiği görüşüne dayandırılmıştır (Ünal, 1991: 749-750). Sözü edilen yeteneklerin geliştirilmesi ve verimliliğin daha üst seviyeye çıkarılabilmesi için bir takım fırsatların çalışanlara sunulması gerekmektedir. $\mathrm{Bu}$ yaklaşım çerçevesinde, eğitim ile bireylere kazandırılabilecek nitelikler arasında okuma-yazma, bilişsel beceriler ve öğrenme yeteneği gibi bireyin tüm işlerinde üretkenliğini arttırabilecek özellikler yanında mesleğe özgü (spesifik) becerilerde sayılabilir (Ünal, 1991: 750). Bu yaklaşım, kadın ve erkeğin farklı meslekler seçmesinin cinsiyet rollerinden kaynaklandığını vurgulamaktadır. Erkeklerin kadınlardan daha fazla çalışma hayatında yer aldığını, kadınların ise ailedeki rollerine uygun olarak doğum ve çocuklara bakmak gibi nedenlerle işlerine ara verdiklerini, ayrıca işgücünün niteliği, genel ve mesleki açıdan erkeğinkine göre düşük olduğu için kadınların daha düşük ücret almalarının ve daha düşük statülü mesleklerde yoğunlaşmalarının normal olduğu ileri sürülmekte, işverenlerin de, kadınların iş yaşamlarının kesintiye uğradığı için erkekleri tercih etmelerinin doğal olduğu belirtilmektedir. Kuram kadın ve erkeğin aynı iş gücünde çalışmalarında bile erkeğin daha yüksek ücret almasını verimlilikle açıklayıp, kadınların bu durumu doğal karşılaması gerektiğini savunmaktadır (Akt. Uygun, 2011: 46; Durmaz, 2016: 46). Kuram, firsat eşitliği olduğunu varsayması açısından ve kadının emek niteliğinin zamanla artmasına rağmen çalışma şartlarında genel bir iyileşmenin olmamasını açıklamakta yetersiz kalmaktadır.

\section{Cinsiyetçi Rol Toplumsallaşması Kuramı}

Cinsiyetçi Rol Toplumsallaşması Kuramına göre, eşitsizlikleri azaltmaya ve ayrımcılığı yasaklamaya yönelik düzenlemelere, rekabet, eğitim, öğretim, becerileri arttırma çabalarına rağmen gelir eşitsizlikleri sürmekte, verimlilik ve eğitim düzeyi aynı olsa bile ücret ve kazanç farklılıkları azalmamaktadır. Yükseköğrenimliler arasındaki kazanç farklılıkları gerileyeceğine yükselmekte, yaşla beraber ilerleme olanakları farklılıkları artmakta, belirli gurupların işsizliğe uğrama bakımından dezavantajları sürekli bir durum arz etmektedir. Kadınlarla erkekler formel olarak eşit haklarla rekabet edebilecek bir konuma getirilmiş olsalar bile, piyasaların fiilen kurumsal olarak işleyiş biçimleri çerçevesinde elde edilen sonuçlarda eşitlik sağlanamamaktadır (Arın, 1992: 176). Kurama göre, eşitliğin sağlanmamasının temelinde bireyler çocukluk dönemlerinden itibaren içinde yaşadıkları toplumun kendi cinsiyetlerine atfettiği özelliklere uygun olarak yetiştirilmektedirler. Çocukluk döneminde yerleştirilen bu tutumlar ilerde mesleki tercihlere de yansımaktadır. Erkeklerin ailenin koruyucusu olarak otoriter ve daha saldırgan, karar verici olmaları; kadınların ise ev işleriyle ilgilenen, korunmaya muhtaç olmaları, farklı iş alanlarında yoğunlaşmalarını sağlamaktadır. Kadınlara ev işlerinin uzantısı meslekler uygun görülürken, erkeklere daha çok fiziksel, cesaret isteyen işler ya da mekanik ve sayısal işler uygun görülmektedir (Şenesen ve Pulhan, 2000: 11). Bireyler işgücü piyasasına girmeden önce cinsiyetçi rol toplumsallaşmasının savunduğu bu görüşe paralel olan süreç devreye girmekte ve kadınlardan öğretmenlik, kuaförlük, aşçılık gibi kadınlara özgü meslekler; erkeklerden de şoförlük, avukatlık, yöneticilik gibi erkeklere özgü meslekler tercih etmeleri beklenmekte; genellikle de tercihler bu yönde yapılmaktadır (Şener, 2011: 13). Bu kuramın, kadınların 
daha az statülü ve daha az ücret karşılığında yapılan işleri kendi iradeleriyle seçtikleri ve kendilerine karşı yapılan cinsiyet ayrımcılığını yine kendilerinin belirlemiş olduğu görüşünü benimsediği için tam olarak gerçeği yansıtmadığı düşünülmektedir. Kadınların seçimlerini kendilerinin yaptığı görüşünün toplumsal cinsiyet şeması kuramı ile bağlantılı olduğu düşünülmektedir. Çocukluk döneminde cinsiyet şemalarını oluşturan birey, yetişkinlikte de bu şemalara uygun meslekleri tercih ederek tutarlı davranmaktadir.

\section{Feminist Kuram}

Feminist Kurama göre, kadın-erkek ayrımcılığının sağlıklı temelleri yoktur. Kadınlar hemşire olmayı seçiyor, emlakçı olmuyorlarsa bunun sebebi kadınların erkeklerden biyolojik olarak farklı olmalarında değil, toplumda geçerli olan kültürel farklılıkta aranmalıdır. Kadın ailesinden ayrı yaşamayı, kendi parasını kazanmayı ve harcamayı, tek başına seyahat etmeyi öğrenmelidir. Bu tür bir kadın imajı tarihsel kadın imajına ters olduğu için tepkiye neden olmaktadır (Güriz, 2011: 68-9). Bu açıdan kuram, performans değerlendirmelerinin cinsiyetten bağımsız olarak yapılmasının, mevcut bakış açısına zenginlik katacağını ve iktisadi açıdan daha verimli olacağını savunmaktadır (Işık ve Serdaroğlu, 2015: 6). Feminist kuram sadece cinsiyete dayalı işbölümünden kaynaklanan sorunlara çözüm aramakla kalmamakta; aynı zamanda toplumda yer alan ataerkilliğin çözümlenmesi konusunda da çaba sarf etmektedir. Feminist kuramcılar da kendi aralarında liberal feministler ve radikal feministler olarak ayrılmaktadırlar. Liberal feministler, örgütlerin kendi yapılarında oluşturdukları, kadınların bulundukları pozisyonda ilerlemelerini engelleyici ayrımcılık uygulamalarının değiștirilmesinin ve her iki cinsiyetin de eşit olanaklara sahip olduğu politikalar belirlemesinin cinsiyet ayrımcılığını ortadan kaldıracağını ileri sürmektedirler (Özkaplan, 2013: 12). Bununla birlikte radikal feministler, kalıplaşmış ve ayrımcılığa sebebiyet veren cinsiyet rolleri tanımlamalarının kaynağının kapitalizmden ziyade ataerkil toplum yapısı olduğunu düşünmektedirler ve onlara göre insanlar arasındaki en temel çatışma şekli cinsiyet çatışmasıdır (Aktaş, 2013: 63).

\section{İşücünde Kadın}

Kuramsal çerçevede literatür taraması yapıldığında genel olarak kuramların açıkladıklarına paralel bulgular elde edildiği fark edilmektedir. Türkiye'de kadınların çalışma oranlarının düşük olması, yukarıda toplumsal cinsiyet eşitsizliği kuramlarında aktarılan "kadına ev içi/ erkeğe ev dışı görevlerin uygun olduğu" bilgisinin öğrenildiğini ve gerçek hayatta uygulandığını doğrulamaktadır. Bu oranlar ve ilgili araştırmalar da incelendiğinde Türkiye'de kadının işgücüne katılım oranı küresel bağlamda da oldukça düşüktür.

Tablo 1 Cinsiyete Göre Dünya'da İşgücüne Katılım Oranları

\begin{tabular}{|l|l|l|}
\hline Ülkeler & Erkekler & Kadınlar \\
\hline Dünya Geneli & 77 & 50 \\
\hline OECD Ülkeleri & 69 & 51 \\
\hline Kuzey Amerika & 69 & 57 \\
\hline Avrupa Birliği & 65 & 51 \\
\hline Doğu Asya ve Pasifik & 79 & 61 \\
\hline Arap Ülkeleri & 76 & 24 \\
\hline Türkiye & 71 & 29 \\
\hline
\end{tabular}

Kaynak: dataworldbank.org, A.T. 20.01.2017

Tablo 1'de 15 yaş üzeri kadınların 2014 yılında iş gücüne katılım oranları ülkeler bazında gösterilmiştir. Görüldügü üzere Arap ülkeleri dışındaki ülkelere göre Türkiye'de kadın işgücü oranları oldukça düşüktür.

Türkiye İstatistik Kurumu (TUIK) 2013/2014 akademik yılı araştırma sonuçları incelendiğinde lisans öğrencisi olarak kayıtlı olan kadın öğrencilerin toplam öğrencilerin \%50.70'ini oluşturduğu görülmektedir. $\mathrm{Bu}$ bulgu eğitimde firsat eşitliğinin sağlanıyor oluşunun bir göstergesi olarak kabul edilebilecekken; işyerlerinde yapılan çalışmalar incelendiğinde aynı bulgulara ulaşılamamaktadır. 
Tablo 2'de 2014 yılı verilerine göre eğitim düzeyine bağlı olarak kadın ve erkeğin aylık gelir dağılımı verilmiştir.

Tablo 2 Cinsiyet ve Ĕ̆itim Durumlarına Göre Aylık Brüt Ücret Karşılaştırması

\begin{tabular}{|l|l|l|}
\hline Eğitim Durumu & $\begin{array}{l}\text { Aylık Ortalama Ücret } \\
(\mathrm{TL})\end{array}$ & $\begin{array}{l}\text { Aylık Ortalama Ücret } \\
(\mathrm{TL})\end{array}$ \\
\hline & Kadın & Erkek \\
\hline İlkokul ve Altı & 1.289 & 1.594 \\
\hline İlköğretim ve Ortaokul & 1.318 & 1.562 \\
\hline Lise & 1.576 & 1.755 \\
\hline Meslek Lisesi & 1.851 & 2.373 \\
\hline Yüksekokul ve üstü & 3.470 & 4.296 \\
\hline
\end{tabular}

Kaynak: TUIK, A.T. 21.01.2017

Tablo 2‘deki TUİK verilerinden hareketle işgücüne katılım ve eğitim arasındaki ilişki incelendiğinde; okur-yazar olmayan kadınların işgücüne katılım oranı \%17,4, lise altı eğitimli kadınların işgücüne katılım oranı \%26,3, lise mezunu kadınların işgücüne katılım oranı \%32,1, mesleki veya teknik lise mezunu kadınların işgücüne katılım oranı \%39,3 ve yükseköğretim mezunu kadınların işgücüne katılım oranı \%72,2'dir. TUİK verilerinde de görüldügü gibi kadınların eğitim seviyesi arttıkça işgücüne katılım oranları da artmaktadır. İşgücü piyasasında kadınların erkeklere kıyasla daha az ücret aldıkları ve sigortasız çalıştırılma oranının kadınlarda daha fazla olduğu bir gerçektir (Kasnakoğlu ve Dayığlu, 1997: 95). Ücret eşitsizliği ile ilgili 1994 yılında Türkiye'de yapılan bir çalışmada yaklaşık olarak \%60 oranında cinsiyete dayalı ücret ayrımcılığ 1 yapıldığı saptanmıştır (Yamak ve Topbaş, 2004: 143).

Kılıç ve Öztürk'e (2014: 108) göre ise kadınlar iş hayatına dâhil olup çalışmak istemekte fakat iş arama sürecinde ve iş hayatında bir takım engel ve zorluklarla karşılaşmakta; bu durum ise kadın istihdamı oranının düşük kalmasında etkili olmaktadır. Kadının istihdamı, kadının kendi ev yaşantısındaki söz hakkını arttırmakta ve bununla birlikte özgüven ve öz yeterlilik algısında da artış görülmektedir. Bu durum sonucunda ise çalışılan alana ve işin değerine bağlı olarak kadınların daha fazla ücret talep edebilecekleri ve daha iyi çalışma koşulları sağlanabileceği düşünülmüştür (Dedeoğlu, 2000: 140).

Başka bir araştırmada kadınların özel sektörde erkeklerden daha düşük ücret aldıkları, daha düşük statülü işlerde çalıştıkları, yükselmeler için erkeklere kadınlardan daha fazla olanak sağlandığı ve kadınların bir işte çalışıp kazandıkları paranın harcanması konusunda eşlerinin kendilerinden daha fazla söz sahibi oldukları bulunmuştur (Akın ve ark., 2008: 94-95). Bu bulgular ev yaşamında kendini gösteren toplumsal cinsiyet kalıp yargılarının ve bunlarla paralel olan uygulamaların iş yaşamında da var olduğunu göstermektedir. Ayrıca insan sermayesi kuramında işgücünün heterojen olduğu, buna göre bir ücret paylaşımının yapılması gerektiği ifade edilmektedir. Fakat bu bulgular ücret dağılımının heterojenlik, verimlilik, yetenek gözetmeden; cinsiyete dayalı olarak yapıldığını göstermektedir. Buna ek olarak aynı kuram eğitim ve meslek ile alakalı olanakların kadınlara erkeklerle eşit şekilde sunulduğunu varsaymaktadır. Fakat bulgular bu ifadeleri desteklememektedir.

2016 yılı verilerine göre işgücüne katılma oranı kadınlarda $\% 36,8$, erkeklerde $\% 78,0$ olarak bulunurken; aynı yıl için istihdam oranı kadınlarda \%32,1, erkeklerde ise \%70,8 olarak bulunmuştur (TÜİK, 2016). Bu veriler göstermektedir ki işgücüne katılımda kadınlar ve erkekler arasında iki kattan daha fazla bir fark hala mevcuttur. Dünya Sağlık Örgütü'nün Çalışma Yaşamında Kadınlar: Eğilimler 2016 Raporu'na göre; kadınlar ortalama olarak erkeklere göre en az 2,5 kat daha fazla ücretsiz ev ve bakım işi yapmaktadır. Bu bulgular da toplumsal cinsiyet eşitsizliği ile ilgili birtakım ipuçları sunmaktadir.

Kadınların emek piyasasına katılımını olduğundan daha az gösteren bir durum da şudur ki işsizlik istatistiklerinde tarımda çalışan kadınlar çalışıyor olarak kabul edilmekte, fakat kentte yaşayan ve belirli alanlarda çalışan kadınlar ücretli işçi olarak kabul edilmemektedir. Evde hazırlanıp parça karşılığ 1 satılan işler ya da diğer elişleri hem istatistiklere yansımamakta hem de kadınlar tarafından 'iş' olarak değil 'serbest zaman aktivitesi' olarak görülmektedir (Dedeoğlu, 2000: 141). Yapılan bir araştırmaya göre İstanbul ilinde yaklaşık 88 bin kadın evde yaptıkları işleri parça başı olarak satmakta ve maddi kazanç sağlamaktadırlar. Bu talebin kaynağı ise hazır giyim ve ihracat potansiyelli endüstriler olmaktadır (Çınar, 1994: 369). Kadınların bu şekilde çalışmayı tercih etmelerinin sebeplerini ise Çınar'a göre (1994: 370), esnek çalışma saatlerini özellikle küçük çocuğu olan annelerin tercih etmesi, 
eşinin kadının dışarda çalışmasına izin vermemesi, komşuların ve diğer tanıdıkların gözünde itibarını yitirme düşüncesi, ücret ve terfi konusunda erkeklerden daha az olanak sunulması ve işyerinde taciz olayları yaşanma ihtimalinin bulunması olarak sıralamaktadır.

Antalya'da yürütülmüş olan başka bir çalışmada da yaş aralığı 15-49 olan kadınların \%75.7'sinin çalışmadığı; bu kadınların \%89.3'ünün ev kadını olduğu, \%2.5'inin yaşları küçük olan çocukları olduğu, \%4.5'inin ise eşinin müsaade etmemesi sebebiyle çalışmadığı bulgularına ulaşılmıştır (Kılıç; 2014: 217). Bu sonuçlardan anlaşılmaktadır ki ikili rol kuramında sözü edilen, kadın için biçilen rollerin çalışma hayatına uygun olmadığı, ev/çocuk/eş üçlüsünün kadının hayatında daha büyük bir yere sahip olması gerektiği görüşü benimsenebilmektedir.

Medeni durumunda kadınların çalışması ya da çalışamaması üzerinde etkili olduğu yapılan araştırmalarda bulunmuştur. Evli veya boşanmış ya da ayrı yaşayan kadınlar, bekâr kadınlara kıyasla daha az iş yaşamına katılmakta iken; evli kadınlar ise boşanmış ya da ayrı yaşayan kadınlardan daha az iş yaşamına katılmaktadır (Kılıç ve Öztürk, 2014: 117). Bu sonucun altında yatan sebeplerden birinin de elbette ki kadının işgücü piyasasına katıldığında evini, eşini ve çocuklarını ihmal edeceği düşüncesi olduğu dikkat çekmektedir.

Evlilik ve ev içindeki yaşantının incelendiği çalışmalarda genel olarak, erkeklerden ziyade kadınların evlilik öncesi cinsel ilişkide bulunmaktan kaçınması gerektiği, kadının şiddet görme durumunda bunu gizlemesi gerektiği, temizlik işlerini yapan ve çocukla ilgilenen ebeveynin yoğunlukla anne olduğu ve olması gerektiğine ilişkin görüşlerin yaygın olduğu fark edilmektedir (Vefikuluçay ve ark., 2007: 13). Dolayısıyla çocukluktan beri bu şekilde oluşan ve devam eden yaşam tarzının iş yaşamında daha farklı devam etmesi de mümkün olmamaktadır.

Vefikuluçay ve arkadaşlarının (2007: 26) yaptıkları araştırmada da üniversite öğrencilerine toplumsal cinsiyetçi kalıpları yansıtan ifadelerin bulunduğu ölçek uygulaması yapılmış ve araştırmanın sonuçları incelendiğinde üniversite öğrencilerinin de toplumsal cinsiyetçi yapıya sahip oldukları gözlenmiştir. Erkek öğrencilerin ise kız öğrencilerden daha fazla cinsiyetçi tutumlara sahip oldukları görülmüştür. Başka bir çalışmada ise katılımcılara kadının konumu ile ilgili ifadeler ve sorular yöneltilmiş ve evli erkeklerin \%64,3'ünün kadınların görevinin annelik, \%22'si ise ev işlerini yapmak ve kocasına bakmak olarak gördüğü kaydedilmiştir. Kadını, "eşinin hayat arkadaşı" gibi daha eşitlikçi olarak ifade edenlerin oranı ise \%13,8 olarak bulunmuştur (Ökten, 2009: 308). Zaman içerisinde Türkiye'de kadınlar açısından bazı değişmelerden söz edilmesine karşın, ev-aile ve iş hayatı ikilemi, kadınlara hem çalışma hayatında hem de özel hayatında sorunlar getirmektedir ve bu sorunlar da süreklilik arz etmektedir (Kocacık ve Gökkaya, 2005: 204).

Gecekondu mahallelerinde yapılan bir araştırmada aile bireylerinin giderek evden ayrıldıkları ve ailedeki kız çocukları genellikle erken evlendikleri için buralarda yaşayan kadınlar 'uydu işçi' olarak çalışmaktadırlar. Yani hane halkı maddi olarak zorluk yaşamaya başladığı zamanlarda kadınlar da maddi kaynak sağlamak için çalışmaya başlamakta, maddi durum biraz toparlandıktan sonra işten ayrılmaktadırlar (Akt: Dedeoğlu, 2000: 141). Bu durum ise kadınların erkeklerle sosyal açıdan ve işle alakalı eşitlik olanaklarının sağlanmasına bir engel olarak görülmektedir.

Sonuç olarak görülmektedir ki kültürel, ekonomik ve teknolojik gelişmelerle birlikte kadın emeğinin de işgücü piyasasında yer alması gerekliliği doğmuştur ve bunu sağlamak son yılların tartışılan konularından olmuştur. Fakat Türkiye'de de olduğu gibi erkeğin evin reisi, kadının ise ev işlerinin sorumlusu olarak görüldüğü ve toplumsal cinsiyete dair kalıp yargısal davranışların dıșına çıkılmamasının beklendiği toplumlarda, bu durumun iş yaşamında da somut olarak kendini gösteriyor olması kaçınılmazdır. Devletin, çalışma koşullarının iyileştirilmesi ve cinsiyet eşitliğinin sağlanması için uygulamaya koyduğu bir takım hukuki düzenlemeler mevcuttur. Bunlar incelendiğinde 2002 tarihli Medeni Kanun ve 2003 tarihli 4857 Sayılı İş Kanunu ile cinsiyet ayrımcılığını destekleyen maddelerin kaldırıldığı ve kadın erkek eşitliğinin sağlanmaya çalışıldığı görülmektedir. Ayrıca 2004 yılında Anayasa'da 10. Madde değiştirilmiş ve "Kadınlar ve erkekler eşit haklara sahiptir. Devlet bu eşitliğin yaşama geçirilmesini sağlamakla yükümlüdür" maddesi konulmuştur. Dedeoğlu (2009: 41-54), bu değişiklikleri incelemiş ve şu şekilde çıkarımlarda bulunmuştur: 4857 Sayılı İş Kanunu 5. maddesinde eşit iş için eşit ücretten bahsedilmektedir fakat bu madde uygulamada zayıf kalmıştır. Çünkü bu kanun çalışanların çoğunun kadın olduğu geçici ve yevmiyeli olarak ev işlerinde çalışanları kapsamamaktadır. Ayrıca eşitlik ilkesi dar bir çerçevede tanımlanmamakta ve eleman tedarik sürecini, hizmet içi eğitimleri ve terfi olanaklarını içermemektedir. İşe alımlarda görüşmelere iş görüşmelerine giden kadınlara çoğunlukla işle alakalı olmadığı halde medeni durumları ve çocuk düşünceleri sorulmaktadır 
(Dedeoğlu, 2009: 53). Bununla birlikte İş Kanunu maddelerinde yer alan tazminat kavramı kadınların evlilik ve doğum sonrası işten ayrılmaları durumunda tazminat talep edebileceklerini söylemektedir. Bu durum kadınları çalışmaları yerine evde kalmaları için teşvik etmekte ve ödüllendirmektedir. Aynı madde erkekler için söz konusu olmamaktadır. Benzer şekilde kanunda doğum ve annelik izninin kapsamı incelendiğinde izinler hep anneye verilmekte, bu izinlerle aslında annenin işini kolaylaştırmak hedefleniyor olsa da sonuç böyle olmamaktadır. Bu sebeple babaya da çocuk bakımı için izin verilmesi konusu gündeme gelmiş, fakat izinlerin işlevsel kullanılmayacağının öngörülmesi sebebi ile uygulamaya konmamıştır.

Yine aynı kanunda yer alan Gebe ve Emziren Kadınların Çalıştırılma Şartlarıyla Emzirme Odaları ve Çocuk Bakım Yurtlarına Dair Yönetmelik incelendiğinde görülmektedir ki kadın işçisi bulunan belirli büyükteki işyerlerinde okul öncesi çocuklar için eğitim merkezi olması gerektiği yazmakta fakat uygulamada çoğu işyerinde böyle bir kısım bulunmamaktadır.

Gerek sözü edilen yasal düzenlemeler gerekse örgütlerde kadın istihdamını arttırmaya ve eşitsizlikleri ortadan kaldırmayı amaçlayan kurallar uygulamada zayıf olmakla birlikte erkeklerin çocuk bakımından sorumlu değilmiş gibi algılanmasına ve tüm sorumluluğun kadına yüklenmesine sebep olmaktadır. Bu sebeple düzenlemelerin yeniden gözden geçirilmesinin ve erkeğin ev işleri ve çocuk bakımında kadınla işbölümü yapmasını ve kadının çalışma hayatına katılmasını özendirici maddelerin de eklenmesinin gerekli olduğu düşünülmektedir. Toplumsal cinsiyet eşitsizliğinin ilk öğrenildiği yer olan ailede cinsiyetçi aktarımların şekil değiştirip daha eşitlikçi bir hale bürünebilmesi için farklı illerde ve bölgelerde planlı toplumsal cinsiyet eğitimleri verilmesinin ve bu eğitimlerden sonra eğitimin etkililiğinin değerlendirilmesi için tekrarlı ve karşılaştırmalı çalışmalar yapılmasının faydalı olabileceği düşünülmektedir. Maddi ve manevi hakların adaletsiz dağılımı engellendiği zaman iki cinsiyetin de topluma daha faydalı olmaları mümkün olacaktır.

\section{YÖNTEM}

Araştırmada nitel araştırma yönteminin kullanılması uygun görülmüştür. Nitel araştırma yönteminin tercih edilmesinin nedeni; araştırma kapsamına alınan kadın akademisyenlerin sınırlı sayıda olması ve bu sınırlı sayıda olan kadınlara derinlemesine araştırma yapılmasından kaynaklanmaktadır. Nitel araştırmalarda örneklem grubunun büyük olmaması gerekir. Örneklem grubunun büyük olması gözlem ve görüşme yoluyla elde edilen geniş çaplı verilerin analizinde zorluklar yaşanmasına neden olacaktır. $\mathrm{Bu}$ açıdan nitel araştırma, katılımcı bireylerin duygularını, düşüncelerini, isteklerini ve yaşantılarını rahat, özgürce ifade etmelerini sağlar ve bu yöntemde daha çok görüşme tekniği kullanılır (Kılıç, 2012: 99). Nitel araştırmalarda 3 tür görüşme yaklaşımı vardır. Bunlar sohbet tarzı görüşme, görüşme formu ve standart açık uçlu görüşme tekniğidir (Çıkmaz ve ark, 2006: 1250).

Çalışmada kadın akademisyenlerle yapılacak görüşmelerin, sohbet tarzı görüşme tekniği kullanılarak yapılması planlanmıştır. Sohbet tarzı görüşme tekniği genellikle araştırmacının gözlem amacıyla doğrudan ortama katıldığ 1 araştırmalarda kullanılır. Sorular doğal akış1 içinde sorulur ve görüşülen birey kendisiyle görüşme yapıldığını bile fark etmeyebilir (Aksoy, 2005: 12; Yılmaz ve Şaşmaz, 2012: 907).

Sohbet tarzı görüşme tekniği kapsamında, sonuçların elde edilip araştırmaların derinlemesine gerçekleştirilmesi açısından yerinden kuram stratejisinin kullanılması uygun görülmüştür. Yerinden kuram stratejisi araştırma sorularında esnek olmayı desteklediğinden ve elde edilen bilgilerin derinlemesine araştırılmasına firsat verdiğinden (Akt. Kılıç, 2012: 99) mülakat formu araştırma kapsamına alınan 7 evli ve 7 bekâr kadın akademisyene uygulanmıştır. Ayrıca; yerinden kuram stratejisinde, bilgilerin elde edilmesi ve analizi için belirlenmiş prosedürler kullanılır ve "bireysel süreçleri, kişilerarası ilişkileri ve bireylerle geniş sosyal süreçler arasındaki karşılıklı etkileri çalışmak uygundur" (Aksoy, 2005: 99) ilkesinden yola çıkılarak yerinden kuramın temel yöntemlerini aşağıdaki şekilde siralayabiliriz:

- $\quad$ Araştırmanın bilgi toplama ve analiz süreçlerinde doğrudan yer alma

- $\quad$ Analitik kodların ve kategorilerin, önceden belirlenmiş hipotezlerden değil elde edilen bilgilerden üretilmesi

- Davranışı ve süreçleri açıklamak için orta düzey teorilerin geliştirilmesi

- $\quad$ Kayit tutma 
- $\quad$ Teorik örnekleme; belli bir grubu temsil etmek için değil teoriyi yapılandırmak için örnekleme yapmadır (Kılıç, 2012: 99).

\section{Bilgi Toplama Araçları ve Süreci}

Araştırmaya katılan örneklemden bilgiler, gözlem ve derinlemesine görüşmeler, ses kaydı yoluyla toplanmıştır. Mülakat ve gözlem formlarında amaçlara uygun açık uçlu, derinlemesine bilgi talep eden sorular sorulmuş ve veriler yapılandırılmış 22 soru aracılığıyla toplanmıştır. Ön taslaklarla şekillendirilen araştırma soruları "kişisel bilgiler, toplumda kadına yönelik şiddet algısı, akademisyenlerin kadına yönelik şiddeti algılama biçimleri ve kadına yönelik ekonomik şiddet algısı" olmak üzere dört bölümden oluşmaktadır. Konunun mahiyeti açısından ekonomik şiddetle ilişkili sorular genel şiddet algısını ortaya koyan sorulardan sonra verilmiştir.

Alan uygulaması 18.09.2016-03.01.2017 tarihleri arasında Düzce Üniversitesi'nde kadın akademisyenlerin ofislerinde yapılmıştır. Araştırmanın evrenini 122 kadın akademisyen (12 Profesör, 22 Doçent ve 98 Yardımcı Doçent) oluşturmaktadır. Araştırmanın nesnelliğini koruması için fakülte isimleri belirtilmekten kaçınılmıştır. Profesör, Doçent ve Yardımcı doçent seviyesinde 14 akademisyenle (1 profesör, 3 Doçent, 10 Yardımcı Doçent) görüşme yapılmıştır. Araştırma daha çok akademisyenle yapılmak istenmesine rağmen, konunun hassas olması sebebiyle bazı birimlerde çalışan kadın akademisyenlerle sağlıklı bir iletişim kurulamamıştır. Yapılan ön görüşmeler sonucunda 22 kadın akademisyen görüşme yapmayı kabul etmiş, görüşme sürecinde akademisyenlerin yoğunluğundan 14'üyle görüşme yapılabilmiştir. Araştırmanın bu üniversitede yapılmak istenmesindeki temel düşünce, kuruluşundan beri 3 dönemdir kadın rektöre sahip olmasındandır. $\mathrm{Bu}$ durumunda araştırmada daha özgür bakış açılarının ön plana çıkabilmesine imkân sağlayacağı düşünülmüştür.

Uygulama sürecinde kadın akademisyenlerle iletişim kurarak çalışmanın amaçları ve katılımcı profili anlatılmış, araştırmanın önemi ve gizliliği uzun uzun uygun dille ifade edilmiş ve görüşme öncesinde samimi bir ortam yaratılmıştır. Görüşme sürecinde ses kaydı kullanılmış (örnekleme ses kaydı noktasında önceden bilgi verilmiş ve rızaları alınmıştır) her görüşme sonucunda görüşmenin önemli noktaları yazıya dökülmüştür.

Görüşme sonucunda elde edilen veriler yorumlanırken, görüşme yapılan kişilerin ifadelerine yer verilmiş, bu süreç gerçekleşirken görüşmecilerin isimleri değil, oluşturulan kodsal ifadeler kullanılmıştır. Örneklemin sıkıntı yaşamaması için fakülte ve bölümlerin tanımlayıcı ifadelerinden özenle kaçınılmıştır. Bazı örneklemin görüşme sırasında sorulara cevap verirken isteksizliği ve çekingenliği fark edilmiş, görüşmecilerin rahat ifadeler kullanması için hassasiyet ve samimiyet yansıtılmaya çalışılmıştır. Görüşmeler sırasında görüşme formları çok az değişikliklere uğramış, temel bakış açısına aykırı davranılmamıştır. Görüşmelerin akışına göre teorik-pratik karşılaştırılmasını yapmaya yönelik sorularda sorulmuş, görüşme sonucunda hedeflenen bilgilere ulaşılmıştır. Heterojen bir katılımcı profili sağlanmış, kadına karşı ekonomik şiddet noktasında evli-bekar kadınlardan benzer ve farklı bakış açıları elde edilmiştir.

\section{Verinin Analizi ve Yönetimi}

Derinlemesine bireysel görüşmeler, kayıtların çözümlenmesi, araştırmacı notlarının bilgisayar ortamına aktarılması ve analiz yöntemi gerçekleştirilmiştir. Araştırma sonucu, elde edilen temalar, doğrudan aktarımlar ve sayılara dayanmayan, gerçekçi bir resim ortaya koyan bir tarzda hazırlanmaya çalışılmıştır.

Bu süreçte derinlemesine yapılmış olan bireysel görüşmeler yoluyla elde edilen görüşme kayıtları teker teker bilgisayar ortamına aktarılmıştır. Görüşmelerin tümü Türkçe olarak yapılmıştır. Tüm görüşme kayıtları sistematik olarak bilgisayar ortamına aktarıldıktan sonra, görüşmeler tekrar tekrar bilgisayardan okunarak temalar ve ortaklıklar oluşturulmuştur. Tekrarlanan okumalar "kodlama" yöntemiyle kavram, kategori ve temalar altında birleştirilmiştir.

Yerinden kuramda kodlama ve analiz üç süreçten geçmektedir; açık kodlama (bilgiyi incelemek, karşılaştırmak, kavramsallaştırmak ve kategorize etmek); aksiyel kodlama (kategoriler arasındaki ilişkilere dayanarak benzer kavramları birleştirme) ve seçici kodlama (asıl fenomeni ya da ana kategoriyi tanımlama ve açıklama) (Strauss and Corbin, 1998: 65). 
Bu araştırmada kodlama süreci "açık kodlama" ile başlamış ve bilgiler kavramsal parçalara ayrılmıştır. Daha sonra daha büyük kavramlar ya da çatılar altında birleştirilmiştir. Kavramların altında birleştirildiği bu daha büyük yapılara "kategori" adı verilmektedir. Daha sonra bu kategoriler "temalar" altında birleştirilmiştir. Son olarak elde edilen temalar bir veya birkaç çatı altında birleştirilerek teori (genel çatı) oluşturulmuştur.

\section{Araştırmanın Soruları}

Sosyal statü açısından toplumsal cinsiyet farkı gözetildiğinde üst sınıfa mensup olan kadın akademisyenler kadına karşı ekonomik şiddet olgusunu nasıl anlamlandırmaktadır? Araştırmamızda bu temel soruya yanıt bulmak için aşağıda belirtilen alt sorulardan hareket edilmiştir.

*Kadın akademisyenlere göre, kadına karşı ekonomik şiddet ile aile yapısı arasında bir ilişki var mıdır?

*Kadın akademisyenler, kadınların eğitim düzeyindeki artış ile ekonomik şiddete maruz kalma arasındaki ilişkiyi nasıl anlamlandırmaktadır?

*Kadın akademisyenler, kadınların ekonomik özgürlükleri ile şiddeti kabullenmeleri arasında bir ilişki olup olmadığını nasıl anlamlandırmaktadır?

*Kadın akademisyenler, ailenin ekonomik gelir düzeyinin kadına karşı ekonomik şiddete etkisini nasıl anlamlandırmaktadırlar?

*Kadın akademisyenler, aile içindeki rol ve statü dağılımının kadına karşı ekonomik şiddetle ilişkisini nasil anlamlandirmaktadirlar?

*Kadın akademisyenler, kadına karşı ekonomik şiddetin çalışma yaşamında şekillenmesi ve boyutlarını nasıl anlamlandırmaktadırlar?

*Kadın akademisyenler, medyada kadına yönelik çıkan haberlerin kadın ve erkeklerin algılarına etkilerini nasil anlamlandırmaktadırlar?

*Kadın akademisyenler, toplumdaki kadına yönelik hukuksal düzenlemeleri nasıl anlamlandirmaktadirlar?

*Kadının ekonomik özgürlüğünün diğer şiddet türlerine etkisini kadın akademisyenler nasıl anlamlandırmaktadırlar?

\section{BULGULAR}

Tablo 3 Kadın Akademisyenlerin Tanımlayıcı Özellikleri

\begin{tabular}{|l|l|l|l|l|}
\hline Örneklem & Yaş & $\begin{array}{l}\text { Eğitim } \\
\text { Durumu }\end{array}$ & Medeni Durum & Unvan \\
\hline EK1 & 47 & Doktora & Evli & Profesör \\
\hline EK2 & 38 & Doktora & Evli & Doçent \\
\hline EK3 & 37 & Doktora & Evli & Doçent \\
\hline EK4 & 42 & Doktora & Evli & Dr. Öğrt. Üyesi \\
\hline EK5 & 39 & Doktora & Evli & Dr. Öğrt. Üyesi \\
\hline EK6 & 33 & Doktora & Evli & Dr. Öğrt. Üyesi \\
\hline EK7 & 30 & Doktora & Evli & Dr. Öğrt. Üyesi \\
\hline BK1 & 40 & Doktora & Bekâr & Doçent \\
\hline BK2 & 44 & Doktora & Bekâr & Dr. Öğrt. Üyesi \\
\hline BK3 & 43 & Doktora & Bekâr & Dr. Öğrt. Üyesi \\
\hline BK4 & 42 & Doktora & Bekâr & Dr. Öğrt. Üyesi \\
\hline BK5 & 42 & Doktora & Bekâr & Dr. Öğrt. Üyesi \\
\hline BK6 & 32 & Doktora & Bekâr & Dr. Öğrt. Üyesi \\
\hline BK7 & 30 & Doktora & Bekâr & Dr. Öğrt. Üyesi \\
\hline
\end{tabular}

\section{Temalar Ekseninde Kadın Akademisyenlerin Kadın ve Şiddet Algısı}

Katılımcılar hakkında tanımlayıcı bilgiler verilmeye çalışıldıktan sonra niteliksel metodolojide gerçekliğe ulaşmada üstenci bir bakıştan ziyade, araştırmaya konu olan aktörlerin düşünce, yorum, anlamlandırma, beklenti, tutum ve davranışlarından doğru bir bakış sergilenmesi gereklidir (Kılıç, 2012: 114). Bu bakışın sergilenmesi için kadın akademisyenlerle yapılan görüşme sonucunda elde 
edilen veriler benzer kavramlar, kategoriler ve temalar altında toplanarak bütünleşik bir bakış açısı sunulmaya çalışılmıştır.

Şekil 1'de kadın akademisyenlerin kadına yönelik şiddet/ekonomik şiddet olgusunu nasıl anlamlandırdıkları, nasıl izah ettiklerini açıklamak için oluşturulan temalar bulunmaktadır. Tema 1 altında; kadının toplumdaki yerini açıklamak için geleneksel cinsiyet rollerinin nasıl şekillendiği ve toplumun kadının iş gücüne katılımına nasıl baktığı ile kadın akademisyenlerin kadının çalışmasına yönelik tutumları ortaya konulmaya çalışılmıştır. Tema 2 altında; genel olarak kadına yönelik şiddetin nasıl algılandığ1 ortaya konulmaya çalışılmıştır. Burada kuramsal yaklaşımların etkisi ile çeşitli parametrelere göre şiddet oranının azalıp azalmayacağı üzerinde durulmuştur. Ayrıca şiddete ilişkin toplumsal düzenlemelerin etkileri kadın akademisyenlerin gözünden saptanmaya çalışılmıştır. Tema 3 altında; kadına yönelik ekonomik şiddet olgusu analiz edilmeye çalışılmış, kadın akademisyenlerin bu şiddet türüne maruz kalma durumları irdelenmeye çalışılmış, ekonomik şiddetin artması ya da azalmasında etkili olan faktörler analiz edilmeye çalışılmıştır. Her bir tema altında yer alan kategoriler, görüşmecilerin ortaya koyduğu kavramlardan hareketle olduğu gibi aktarılmıştır.

Tema 1

Kadının Toplumdaki Yeri

Tema 2

Kadına Yönelik Şiddet Algısı

Tema 3

Ekonomik Şiddet Algısı

Şekil 1. Temalar ve içerikleri

Tema 1: Kadının Toplumdaki Yeri
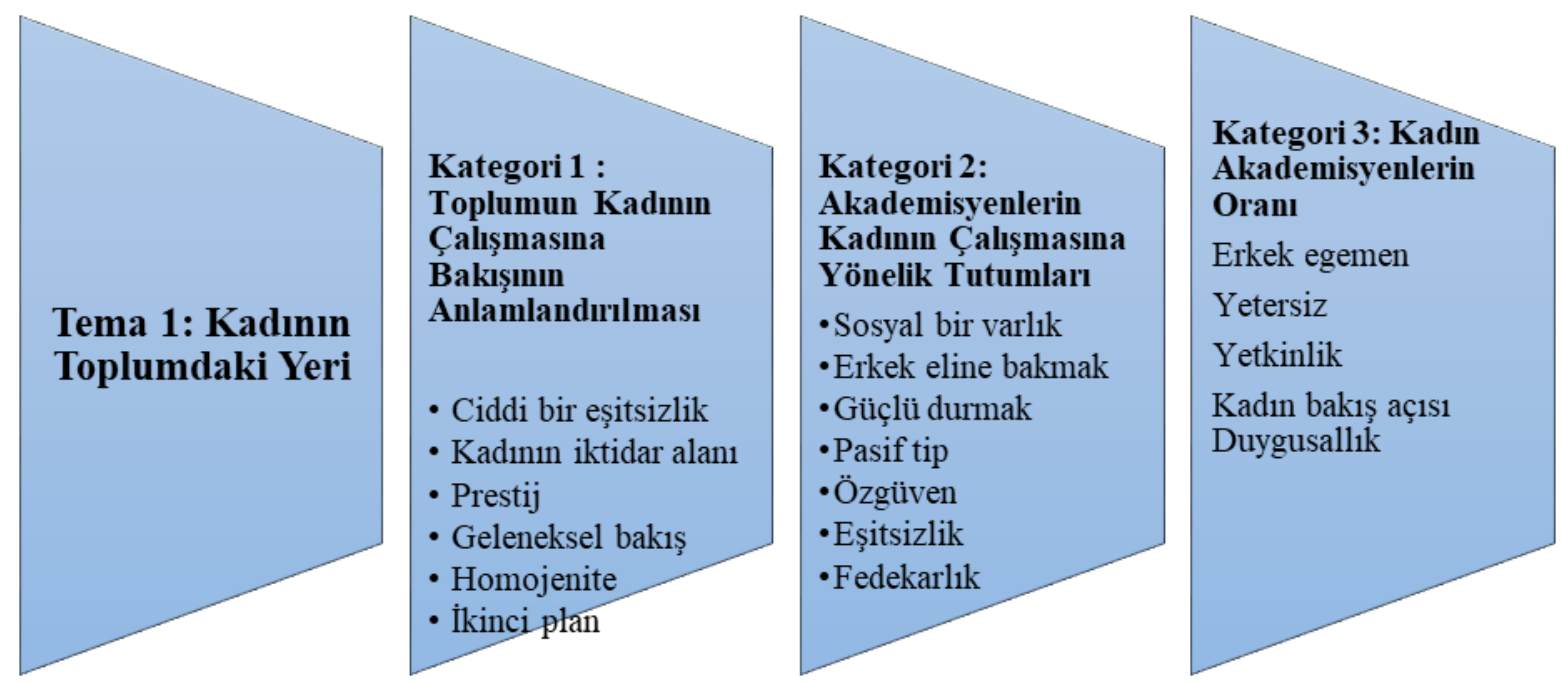

Şekil 2. Tema 1 kadının toplumdaki yeri

Kadının toplumdaki yeri asırlardır ev ile sınırlandırılmış, işlevi ev işi ve çocuk yetiştirme olarak belirlenmiştir. On dokuzuncu yüzyıldan itibaren hızla gelişen endüstrileşme, geleneksel tarım toplumlarında ailenin ücretsiz işçisi olarak ağır iş yükü taşıyan kadına, eğitim görme ve ev dışında ücretli çalışma olanakları sağlamıştır. Eğitim düzeyinin yükselmesi ve toplumdaki işlevinin çeşitlenmesi ile kadın sosyal haklarını genişletmek için mücadeleye başlamıştır. Ama toplumun geniş kesiminde kadın işgücüne yönelik geleneksel bakış tarzının hala sürdüğü gözlenmektedir. Toplumun ve kadının kendisine biçtiği öncelikli rol "eş ve anne" ve bunun doğal sonucu olarak "ev kadını" olduğu sürece, kadın işgücünün "ucuz emek", "yardımcı aile işçisi" ve benzeri şekillerde tanımlanması kaçınılmaz olmaktadır. Kadınların esas istihdam biçimi de bu tanımlarla uyumlu bir şekilde ücretsiz aile işçisi olarak çalışmak olmaktadır. Kadının toplumsal yaşamda yeri noktasından Cumhuriyetten günümüze hukuksal anlamda birçok topluma göre daha öncelikli ve pozitif adımlar atılmasına rağmen, 
geleneksel değer yargılarının hâkimiyetinin günümüzde kadınların üçte ikisinden fazlasının ücretsiz aile işçisi olmasının önüne geçememiştir.

$\mathrm{Bu}$ durumun arkasında yatan sebeplerin izahı noktasında akademisyenlerin gözünden iki kategori ortaya konulmaya çalışmış ve bu kategorilerde toplumun genelinin kadın iş gücüne bakışının nasıl olduğu, geleneksel cinsiyet rollerinin nasıl şekillendiği ile akademisyenlerin kadının çalışmasına yönelik düşünceleri tartışılmaya çalışılmıştır.

Görüşmeye katılan kadın akademisyenlerin kadınların toplumsal yaşamdaki yerini nasıl anlamlandırdıklarını ortaya koyabilmek için, akademisyenlerin mülakatlara verdikleri cevaplardan hareket ederek; eşitsizlik, kadının iktidar alanı, geleneksel bakış, homojenite, prestij gibi ifadeler kavramsallaştırılarak yukarıdaki tabloda verilmiştir. $\mathrm{Bu}$ kategorideki kavramsallaştırmaların bir birleriyle yakın ilişskileri söz konusu olduğundan ve anlam kargaşası yaşamamak için, akademisyenlerin ifadelerini bütüncül bir şekilde vermek daha anlamlı olacaktır. Kategori altındaki kavramsallaştırmalarda evli ve bekâr kadın akademisyenlerin benzer bakış açısı ortaya koyarak "toplumda kadına verilmiş statünün, ikinci planda olmak üzerine kurulduğunu” genelleştirmekte fayda vardir.

$\mathrm{Bu}$ durumu EK7 kodlu akademisyen, günümüzde çok yoğun bir şekilde kadının halen daha çalıştırılmak istenmediğini ama kadının ekonomik anlamda değil sadece, sosyal sermayesini arttırmak içinde çalışması gerektiğini yoksa ikinci plana atılan kadın statüsünün aşılamayacağını şu şekilde ifade etmektedir: ...Bence Türkiye'de ne yazık ki halen daha büyük bir oran kadının çalışmasını istemiyor. Bence kesinlikle kadın çalışmall, maddi olarak ister ihtiyacı olsun isterse olmasın... Türkiye geneli için konuştuğumda aslında ekonomik seviyesi çok düşük olan insanlar var. Onlarında birçoğunun zaten kadını ikinci plana attıklarını düşünüyorum. Ne yazık ki çalışan kadın oranı oldukça düşük ülkemizde. Elbette bu durumun arkasinda geleneksel cinsiyet faktörleri bulunmakta. Bu sebeple ikinci planda kalan kadın saygınlı̆̆ını tam anlamıyla elde edemiyor. Bu açıdan yaratıcı, kendini dönüştürücü bir faktör olarak kadın var olmalıdır toplumda. Bu da çalışmaktan geçer ve kadınların güveni artar. Bu da saygınlı̆̆ arttırır...(Dr. Ö̈̆rt. Üyesi, 30, Evli)

Kadının toplumsal yaşamda ikinci planda kalmasında toplumun bakış açısında "kadının yeri evidir" düşüncesinin hâkim olduğunu savunun EK3 kodlu akademisyen kadının işinin ağır olmamas1 gerektiğini kendinden örnek vererek şu şekilde izah etmektedir: ...Toplumun geneli kadının yeri evidir düşüncesi savunuyor. Aslında kadının işinin çok ağır olmamasını bende destekliyorum. Kendimin de işi çok ă̆ırdı. Doktora yaptı̆̆ım zamanlar çok ă̆ırdl. Il dışında araziye gidiyorum geliyorum o zamanlar belki ăgırdı yaşam şartlarım. Ama birkaç senedir biraz daha rutine bindiği için daha rahat bir yaşantım var dolayısıyla şuan bir çocuğum var ona daha çok vakit ayırabiliyorum. Yani kadın evli ve çocuk sahibiyse çalışma şartlarının biraz daha iyi olmasl gerekiyor. Toplumda bundan yana benim kendi yaşadığım hayattan da bunu anlıyorum avantajlarını görüyorum. Ne kadar ağır şartlarda olursa kadın o kadar az çocuğuna, ailesine vakit ayırabiliyor...(Doçent, Evli, 37)

Kategori 2 altında araştırmaya katılan kadın akademisyenlerin, kadının çalışmasına yönelik tutumları değerlendirilmeye çalışılmıştır. Bu kategori altında; kadının sosyal bir varlık olması, güçlü durmak, pasif tip, fedakârlık, erkek eline bakmak gibi kavramsallaştırmalardan hareket edilerek ortak genellemelere varılmaya çalışılmıştır. Bu kavramlarda hareketle kadın akademisyenlerin medeni durum gözetmeksizin, kadınların iş hayatına katılmalarını destekleyici söylemler ortaya koyduklarını söylemek mümkündür. Kavramlaştırmalar çerçevesinde kadının çalışmasına yönelik temel tutumlar aynı olsa da, kadınların çalışmalarının gerekçelerinin ortaya konulması noktasında farklı bakış açıları gözlenmektedir.

Kadının kesinlikle çalışması gerektiğini savunan EK4 kodlu örnekleme göre, eğitim seviyesi yükseldikçe birçok şeyden fedakârlık veren bir kadının muhakkak çalışması gerektiğini şu sözleriyle ifade etmektedir: ...Kesinlikle çalışmall. Özellikle üniversite mezunu bir kadın o kadar emek harcadıktan sonra hele de yüksek lisans doktora yapıyorsa çalışması gerekiyor. Ben doktorayı bitirdikten sonra Türkiye'nin genelinde bir kadro arayışı vardır. Genellikle kadro bulamayanların psikolojisi şudur: ben evde börek ya da çörek yapmak için mi yemek yapmak için mi doktora yaptım düşüncesi genelde acı verir çünkü bu sürece gelene kadarki aşamalar zor aşamalar. Birçok şeyden fedakârlık veriyorsunuz. Ĕ̆ger bu aşamalardan geçtiyse mutlaka çalışmalı...(Dr. Öğrt. Üyesi, 42, Evli) Kadının çalışması gerektiğini savunan EK5 kodlu örnekleme göre, kadın çalıştığı taktirde kısır bir döngüden kurtulması, gelişmesi söz konusudur. Kadının gelişiminin ev hayatını düzenlemede de önemli olduğunu şu şekilde izah etmektedir: ...Kadın çalışmalı. Kadın kendi için, kendi gelişimi için 
çalışmalı. Çünkü evdeki hayat kolay bir hayat değil. Kesinlikle burada ev kadınlarını küçümsemiyorum. Şu an ben çallşlyorum ama evdeki işlerin devam etmesi için başka birilerinden yardım almak zorundayım. Başka türlü mümkün değil. Yetişemem yani. Çok fazla kısır döngüye giriliyor evde, kadının ev hanımı olup ta kendini geliştirmesi çok nadir. Kurslara giden kadın sayısı çok az. O yüzden çalışmak kadının gelişimini de sağllyor. Kadın gelişirse evliliğine de katkı sağlar. Bir kere kadın kendini iyi hissediyorsa otomatikmen etrafına çocuklarına ve eşine yaklaşımı güzelleşir. Kadın iyi ise herkes iyi olur...(Dr. Öğrt. Üyesi, 39, Evli)

Kadının çalışması gerektiğini savunan akademisyenlerin ortak ifadelerinde muhakkak kadının ekonomik özgürlüğünü alması gerektiği düşüncesi ön plana çıkmaktadır. Başka birine bağımlı kalmamak ve sosyal bir varlık olmak için kadının çalışması gerektiğini farklı örneklemler şu sözleriyle izah etmektedir: ...Bence mutlaka çalışmalı. Her kadın ekonomik özgürlügünü elde etmek zorunda. İster üniversiteye gider iyi bir iş sahibi olur ama şansızdır gidememiştir kendi eğitim durumuna göre herkes çalışmalı ve kimseye muhtaç olmamalı bence bu kadın içinde erkek içinde insan olarak kendi hayatını kendisi idame ettirebilmeli hiç kimseye muhtaç olmadan...(Dr. Öğrt. Üyesi, 42, Bekâr) ...Bence kesinlikle çalışmallyız, üretimde olmalıyız. Ben bir bireyim bir erkeğin eline bakmak istemiyorum...Ben çok sindiremiyorum yani erkek eline bakmak o yüzden kadın çalışmalı ve birey olmasından ötürü üretimde olmalı. Durumum çok çok iyide olsa çalışmak isterim. Çalışan insan başka oluyor yani çalışan insan değişiyor farklı bir şey bana göre çalışmak, para kazanmanın dışında insanın sosyal bir varlık olmasını să̆llyor. Ben sosyal bir varlı̆̆ım, evden çıklyoruz bayan olarak yani ben çalışmadığım zaman evde iken kendime dikkat etmiyorum yani. Hafta sonları standart bir kadın gibi tek başıma yaşıyorum ama yine de temizliğimi yapıyorum ne bileyim işte değişiyor insan evdeyken, ev haline bürünüyor yani. Pazartesi işe geliyorum birden bire havam değişiyor...(Dr. Öğrt. Üyesi, 40, Bekar) ...Bence çalışmalı tabii ki, bir kere güzel bir şey, hangi iş olursa olsun hiçbir işte çalışmak, para kazanmak kolay bir şey değil. Herkes çok yorularak, çok emek vererek, çok uğraşarak para kazanıyor kadın erkek fark etmez. Ama özellikle bir kadın çalışmalı kendi ekonomik gücünü eline alıp, kendi istediği gibi yaşayabilmeli yani. Bundan kaynakl olan kendine güveni olmalı diye düşünüyorum...(Dr. Öğrt. Üyesi, 32, Bekar) ...Tabii ki kadın çalışmalı. Bence özellikle kadın çalışmalı çünkü bizim toplumumuz gibi erkek egemen olan toplumlarda kadınların hiçbir güvencesi yok. Kendini ekonomik anlamda güvende hissetmeyen kadınlar hakkını arayamıyor. Biraz daha ekonomik yönden güvencesi olan bir kadın haksızlıklara karşı durabiliyor. Fiziksel olsun, psikolojik olsun şiddete karşı durabiliyor. Ekonomik özgürlügü olmadiğında ailesinden destek görebilir mi göremez mi evli insanlar için bahsediyorum zaten bunu kendine yediremiyor. Ailesinden böyle bir şeyi talep etmeyi kendine yediremiyor. Bence mutlaka özellikle kadınların ama küçük ama büyük bir şekilde işinin olması lazım...(Doçent, 40, Bekar)

Kategori 3 altında örneklemin kadın akademisyenlerin oranı ile ilgili algıları tespit edilmeye çalışılmıştır. Örneklemlerin, üniversitelerde çalışan kadın akademisyenlerin oranlarında farklı bakış açıları ortaya koymalarına rağmen, kadınların yönetim alanlarında ciddi olarak yetersiz olduğunu ifade etmektedirler. Kategori 3 başlığı altında erkek egemen, yetersiz, yetkinlik, kadın bakış açısı, duygusallık gibi kavramlaştırmalardan hareket edilerek genellemelere ulaşılmaya çalışılmıştır.

Türkiye'de kadınların genelde sosyal düzen içerisinde özelde akademide yetki ve karar verme mekanizmalarına yeterli ve anlamlı düzeyde katılım gösteremedikleri ifade eden Ünnü ve arkadaşlarına (2014:129) göre, iş ve aile yaşamı arasında denge kurma zorunluluğu ve beraberindeki baskılar, gebelik süreci ve anneliğin getirdiği ek sorumluluklar, toplumsal cinsiyet rollerine ilişkin algilamalar ve cinsiyet eşitsizliği, üst yönetim kademelerine seçim ve terfi süreçlerinin yeterince şeffaf olmaması, üniversiteler başta olmak üzere genel olarak örgüt kültürlerinin maskülen değerlere sahip olması, başta mentorluk olmak üzere kadını destekleyici mekanizmaların eksikliği, kadınların cinsiyetlerine ilişkin maruz kaldıkları stereotipleştirmeleri içselleştirmelerini sebebiyettir. Ünnü ve arkadaşlarının söylemlerine paralel bir şekilde, üniversitelerde kadın akademisyenlerin yeterli olmamasını erkek akademisyenlere oranla daha az olduğundan ötürü eleștiren EK3 kodlu akademisyen benzer bir bakış açısıyla daha çok yönetici pozisyonunda erkek egemen bir yapının hâkim olduğunu şu sözleriyle ifade etmektedir: ...Yeterli bulmuyor sonuçta sayllarl erkeklere göre daha az. Kendi üniversitemizde kadın yöneticiler olsa da yine erkek egemen. Erkeklerin fazla olduğu dĭ̆er üniversitelerde de geldiğimiz İstanbul üniversitesinde de yani nereye bakarsanı bakın erkeklerin daha kalabalı olduğunu görüyoruz...(Doçent, 37, Evli) 
Kadın akademisyenlerin yetersiz olduğu düşüncesini toplumsal açıdan kadın çalışamaz önyargısına bağlı olarak ifadelendirmeye çalışan EK4 kodlu akademisyen, kadınların erkeklerle eşit oranlarda çalışması gerektiğini şöyle ifade etmektedir: ... Tabii ki yeterli değil. Belki de toplumun diğer kesiminde kadın çalışamaz önyargısının söz konusu olmasındandır. Çalışmayıp evde çocuk bakıp çocuklarını büyütmesi yargısı var belki bunu değiștirerek, kadında bir birey ve topluma faydası olabilir. Bazen erkeklerin göremediği küçük ayrıntıları kadınlar çok güzel görebiliyor. O yüzden çalışma ortamında kadınlarla erkekler eşit oranda olursa o ayrıntılarda göz önünde tutulup daha güzel işler ortaya çıkabilir diye düşünüyorum...(Dr. Öğrt. Üyesi, 42, Evli)

Günümüzde kadın akademisyenler, evde veya okulda zamanlarının büyük bir kısmını bilimsel faaliyetlere ayırmaktadır. Kadın akademisyenler bilimsel çalışmalarını mesai saatleri dışında evde de sürdürmek zorundadır. Bir taraftan mesleğinin gereklerini yerine getirmeye çalışırken, diğer taraftan da ilkel toplumlardan günümüze kadar devam eden geleneksel ev işleri, çocuk bakımı ve benzeri işleri yapma zorunluluğu gibi rutin roller, kadınların omuzlarına yüklenmiş görünmeyen bir emek olarak algılanmaktadır. Bu durum günümüz şartlarında da kadın akademisyenleri birçok sorunla karşı karşıya bırakmaktadır. Kadınlar anne, eş, arkadaş, meslektaş, araştırmacı ve bunun gibi pek çok rol ile ilişkilendirilmiş talepleri karşılamak için, kişisel zamanlarından feragat etmek durumundadır (Dikmen ve Maden, 2012: 258). Dikmen ve Maden'in ifadelerini destekleyen bir bakış açısıyla, kadın ve erkek akademisyenlerin çalışma açısından eşit seviyede olmadığını izah eden EK5 kodlu örnekleme göre ise toplumsal cinsiyet rollerine bağlı olarak evli ve çocuklu akademisyenlerin, akademik çalışmalara erkek akademisyenlere göre daha geriden başlama nedenleri izah ederek, bu eşitsizliğin ortadan kaldırılması ve kadın akademisyenlere pozitif ayrımcılık yapılması gerektiğini Avrupa'dan örneklendirerek şöyle izah etmektedir: ...Çok düşük kadın akademisyen sayısı. Arttırılabilir. Kadın ile erkek aynı statüde değerlendiriliyorsa, örneğin doğum yapıp işe başladığında rakiplerin direkt erkek. Ama senin süt izni kullanman gerekiyor. Senin geriden başlayacağını kabul etmeleri gerekiyor. Özel sektörde bu çok daha fazla. Yani kanunlarla yaptırım daha fazla arttırılmak zorunda kadın sayısının arttırılması için. Çoğu bayan bu yüzden işi bırakmak zorunda kalıyor. Aileleri burada değil, çocuklarına kendileri bakmak zorundalar. Bir banka çalışanını düşünün 8 de 9 da geliyor. O zamanda bir seçim yapmak zorunda kalıyorlar. Seçimde tabii ki aile önce geliyor. Örneğin doğumdan sonra işe başladiğımda azami seviyede 10 saat ders aldım. Ö̆̆retim üyesi sıkıntısı vardı bölümde. Ama o 10 saat bile çok zor veriliyordu. Gece uykusuzluk çocuğun anı anını tutmaması, işin dışında başka bir işi yapmak zor oluyor. Koşullar el verseydi bir 6 ay daha çocuğuma bakardım sonra dönerdim. Yurt dışında 2 yıl bu süre. Bu da tabii ki ister istemez bilimden uzaklaşmaya sebebiyet veriyor ...(Dr. Öğrt. Üyesi, 39, Evli)

\section{Tema 2: Kadına Yönelik Şiddet Algısı}

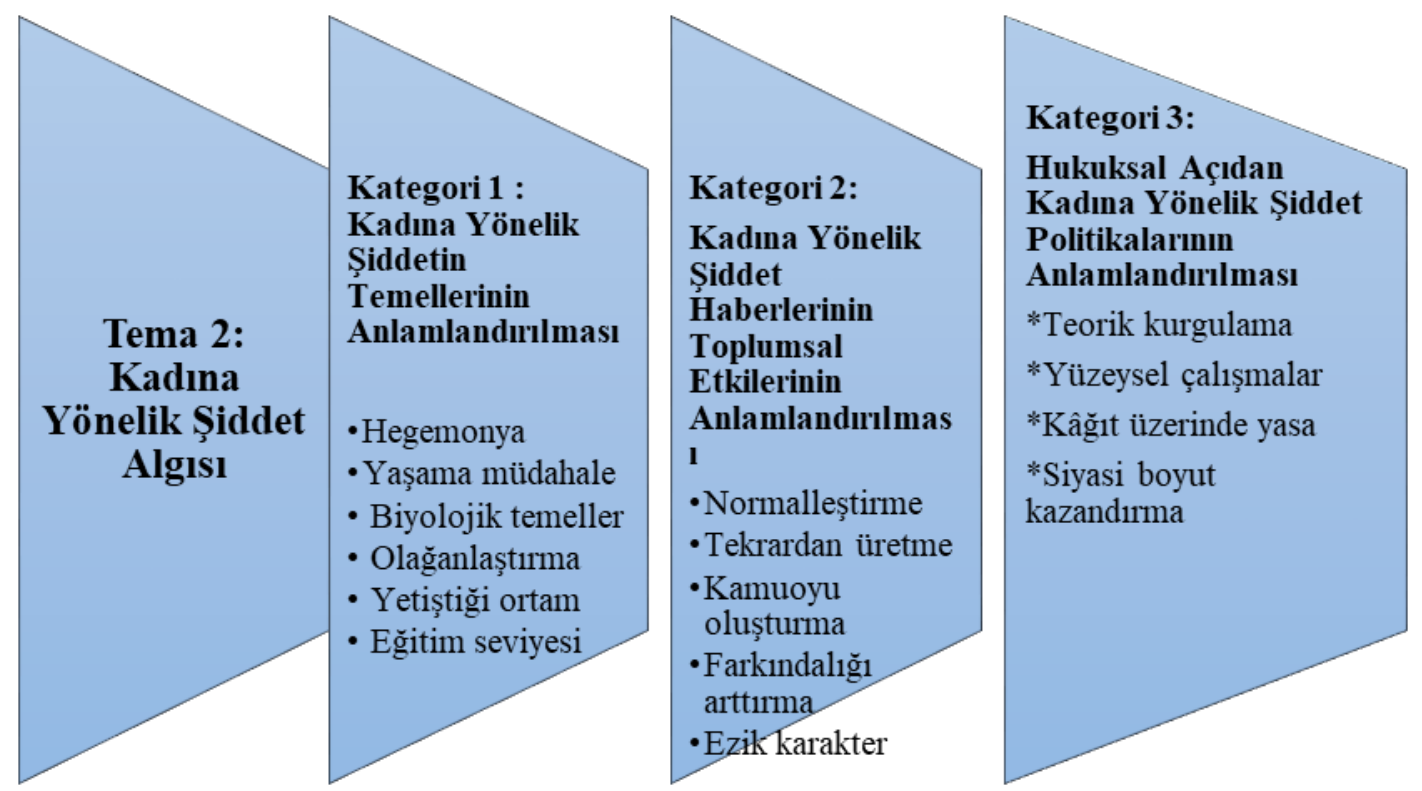

Şekil 3. Tema 2 kadına yönelik şiddet algısı 
Tema 2 altında kadına yönelik şiddet algısı analiz edilirken, kavramsallaştırmalardan hareketle 3 kategori oluşturulmuştur. Kadına yönelik şiddetin farklı boyutlarının kadın akademisyenler tarafından nasıl anlamlandırıldığını analiz etmek için öncelikle kategori 1 başlığı altında; kadına yönelik şiddetin temelleri anlamlandırılmaya çalışılmıştır. Kadına yönelik şiddet türlerinin sorgulandığı ve toplumsal açıdan en çok gözlenen şiddet türünün tespit edilmeye çalışıldığı bu kategoride, kadına yönelik şiddet yoğunluğunda biyolojik ya da sosyal nedenlerin ne kadar etkisinin olduğu da anlamlandırılmaya çalışılmıştır. Ayrıca şiddetin azalmasında ya da artmasında eğitim seviyesinin ne kadar etkili olduğu tespit edilmeye çalışılmıştır. Kategori 2 başlığı altında, medyada çıkan kadına yönelik şiddetle ilgili haberlerin toplumun genelinde nasıl etki bıraktığ 1 kadın akademisyenlerin bakış açısıyla tartışılmaya çalışılmış ve pozitif etkilerin arttırılması için neler yapılması gerektiği kavramsallaştırılmıştır. Son olarak kategori 3 başlığı altında; hukuksal olarak kadına yönelik şiddet politikaları yeterli seviyede olup olmadığ 1 hakkındaki görüşler tespit edilmeye çalışılmış ve Aile ve Sosyal Politikalar Bakanlığı'nın kadına yönelik politikalarının, kadına yönelik şiddeti nasıl etkilediği hakkındaki bakış açıları analiz edilmeye çalışılmış olup, kadına yönelik mobing konusuna nasıl yaklaştıkları da analiz edilmeye çalışılmıştır.

Literatürde kadına yönelik şiddet olgusunun 4 farklı kategoride izah etmeye çalıştık. Bu kategori altında; hegemonya, yaşama müdahale, biyolojik temeller, olağanlaştırma, sosyal nedenler, eğitim seviyesi gibi kavramsallaştırmalardan hareketle toplumda en çok gözlemlenen şiddet türü belirginleştirilmeye çalışılarak, bu şiddet türlerinin arkasında yatan nedenlerin nasıl ifade edildiği ortaya konulmaya çalışılmıştır.

İlk olarak hegemonya kavramsallaştırması altında toplumsal cinsiyete bağlı olarak iki cinsten birinin diğeri üzerinde psikolojik şiddet uygulayarak egemenlik kurmasını ve gücü olanın daha az güçlü olan insan üzerinde baskı yapabileceğini belirten EK1 kodlu örneklem psikolojik şiddeti "güç zehirlenmesi" olarak şu şekilde ifade etmektedir: ...Kadına yönelik şiddet her zaman olmuştur, olacaktır. Çünkü iki cinsiyet arasinda fiziksel bir fark var. Şiddeti burada sadece fiziksel olarak algllamiyoruz. Bir cinsin öbürüne göre egemenlik kurmasl da bence şiddet olarak yorumlanabilir. Birinin daha böyle patron vaziyetinde olması da şiddet olarak algılanabilir. Mobing gibi de düşünebiliriz. Dolaylslyla evet gücü olan herkes güç zehirlenmesi yaşar belki ve bu sirf cinsiyette olarak demeyeyim. Gücü olmayan o gruba karşı bir hegemonya kurmak isteyecek, kendi dolayısıla bir şiddet uygulayacaktır toplumda. Kaçınılmaz bir şey de aslında...(Profesör, 47, Evli)

Toplumsal yaşamda kadına yönelik şiddet söz konusu olduğunda en çok gözlenen şiddet türünün psikolojik şiddet olduğunu belirten EK5 kodlu örnekleme göre, diğer şiddet türlerinin psikolojik şiddetten sonra gelmesi söz konusudur. Psikolojik şiddet olgusunun sadece erkek tarafından uygulanmadığını belirten EK5, bulunduğu sosyal çevrede kedisinin de psikolojik şiddete sıkça maruz kaldığını, erkeğin kendine güvensizliği söz konusu olduğu takdirde tahakküm oluşturmak için fiziksel şiddete başvurduğunu ve eğitimin şiddeti ortadan kaldırmadığını şöyle ifade etmektedir: ...Kadına yönelik bence en büyük şiddet psikolojiktir. Evet, sonrasında fiziksel, cinsel şiddet söz konusu olabilir. Ama önem sırasını sorguladığımızda psikolojik şiddet en önemli olanı diye düşünüyorum. Sadece erkek olarak değil aile olarak ta etrafindaki insanlardan görebilirsiniz. Bu benim çevremde gördüğ̈̈m bir şey. Mesela kayınvalide tarafindan birinci önceliğinin ne olduğunun hatırlatılmast, iğnelemeler etrafimda gördügüm şeyler. O yüzden birincisi psikolojik. Erkek kendine güvensizse o zaman fiziksel şiddet ortaya çıkıyor. Ë̆itimle belki azalıyordur. Ama eğitimle ortadan kalkmıyor diyebiliriz. Son istatistiklere göre ĕgitimli kadınların daha çok şiddet gördüğü açıklanmıştı...(Dr. Öğrt. Üyesi, 39, Evli) Kadına yönelik psikolojik şiddet olgusunun aile içinde karı-koca arasında olmasından ziyade, toplumsal yaşamın her alanında ve toplumumuzun her bölgesinde olduğunu ve birçok defa kendisinin psikolojik şiddete maruz kaldığını belirten BK1 kodlu örnekleme göre, kadınların sosyal hayatta erkekler tarafından yetersiz görülmesi ve yaşamlarına müdahale edilmesi söz konusu. Erkek tarafından oluşturulan kadın tiplemesinin dışında hareket edildiği takdirde ise direkt önyargı, taciz ve dişlanmanın söz konusu olduğu örneklerle şöyle izah etmektedir: ...Kadına yönelik şiddet ülkenin doğusu batısı her yerde çeşitliliklerle olduğunu düşünüyorum. Burada bile ben kadın olarak rahat olmadığımı hissediyorum. Herhangi bir yerde, insanların toplu olarak bulunduklarl yerlerde bir soru sorduğunuzda ya da en basitinden para çekmek için bir banka sirasına girdiğinizde bile yönlendiriyorlar sizi. Adam size bakıp bu işi bu yapabilir bu yapamaz diye düşünmeden orada hani dürtme ihtiyacıyla şuna bas buna bas diye yönlendiriyor. Kaç kere buna şahit oldum ve kavga ettim adamlarla. Yardım istemem ve ben yakanımda kimse olsun da istemem çok fazla dibimde. Uyardığım 
için sen ne biçim kadınsın. İşte böyle diyaloğa girilir mi yabancı biriyle erkeklerle falan diye hakarete bile uğradım. Yine toplu taşımada... Sirf ben o yüzden araba aldım. Çok kaba ve nezaketsiz oldukları için ve kadın olarak sesinizi çıkarmanıza alışık olmadıkları için ben burada kadın olarak çok dışlandığımızı hissediyorum. Yaşadığımız çevrede bile yalnız bir kadın, kimler geliyor kimler gidiyor. Bunlar bile soru işareti bundan rahatsız olabiliyorsunuz. Size çekinmeden soru soruyorlar. Kadını olsun erkeği olsun hiç fark etmez size fütursuzca, küstahça soru sorabiliyorlar. Bu bir yaşama müdahaledir. Bunun toplumda giderek arttı̆̆ını düşünüyorum. Dediğim gibi doğudur batıdır hiç fark etmez. Hiçbir ili ayırt etmiyorum. Çok fazla gezdiğim için gözlemleyebiliyorum. Yani güneye de gittim Akdeniz, Ege kıyllarında bile zaman zaman bunu hissettim. Kadın olarak biraz daha giyimine kuşamına dikkat etmek ihtiyacı duyuyorsunuz. Bence buda bir şiddettir yani benim giyimim kuşamım, oturmam, kalkmam bunu ileri boyutta bir toplum belirleyemez. Belirlememeli...(Doçent, 40, Bekâr)

Son dönemlerde medyada kadına yönelik şiddet haberlerinin yoğun olarak verildiği gözlenmektedir. Yapılan araştırmalarda kadına yönelik şiddetin günümüzde artmasından ziyade geçmişte daha geleneksel ve aile içerisinde çözümlenen ya da çözümlenmeyen bu meselelerin mahrem alanda kalması söz konusu idi. Günümüzde modernleşmeye bağlı olarak, toplumsal cinsiyet bağlamında kadınların daha sosyal yaşama entegre olmalarıyla birlikte bu tür konulara daha hassasiyetle yaklaşılmasıyla, kadına yönelik şiddet haberlerinin de ön plana çıktığı söylenebilir. Araştırmaya katılan akademisyenlerin ifadelerinden hareketle normalleştirme, tekrardan üretme, kamuoyu oluşturma, farkındalığı arttırma, ezik karakter gibi kavramlaştırmalardan yola çıkılarak kategori 2 şekillendirilmeye çalışılmıştır.

Medyada kadına yönelik şiddet ile ilgili çıkan haberlerin ekseri olarak kadını önemsizleştirdiğini, şiddeti meşru hale getirip normalleştirdiğini ve negatif bir etki yarattığını ifade eden EK5, EK7, BK2, BK6 ve BK7 kodlu örneklemler bu durumun nasıl oluştuğunu aşağıdaki gibi (kod sıralamalı) ifadelendirmektedirler: ...Şiddeti teşvik eden bir yönü var. Çünkü diğer şiddet uygulamak isteyenlere de bu kadar şiddet haberinin yayılması olayı olağanlaştırıyor. Oda yaptı oda yaptı. Bilinçlenen kısımda var. Kadına çok fazla şiddet yapılıyor. Toplum adına bir şey yapılmalı diyen tarafta var ama hangi taraf ă̆ır basıyor bilemiyorum...(Dr. Ö̈̆rt. Üyesi, 39, Evli) ... Bence duyarsızlaştırıyor. Çünkü o kadar çok arttı ki. Sürekli haberlerde bu tarz şiddet olaylarını görüyoruz. İşte ne oluyor izliyoruz üzülüyoruz şöyle oldu böyle oldu diye. Hatta bazen daha büyük olaylart izliyoruz. Ne oluyor bir hafta sürüyor bazen insanlar ayaklanıyor, kampanya başlatıyorlar ve sonradan bir süre geçiyor unutuluyor. Sonra tekrar aynı olayı isim değişiyor ama aynı olayı yaşlyoruz. Yaşanan olay değişmiyor ve çözüm bulunmuyor. Duyarsızlaşıyoruz...(Dr. Öğrt. Üyesi, 30, Evli) ...Bence kadınları ayrı etkiliyor adamları ayrı etkiliyor. Kadınları şöyle etkiliyor; ya bu bizim başımıza gelirse diye etkileniyorlar... Erkelerde vay adama bak karısının ağzını burnunu dağıtmış bunu bende yapabilirim diye düşünüyor... Erkekleri olumsuz etkiliyor kadınları da psikolojik olarak bastırıyor bu olaylar. Çünkü neden aynı şeyi yaşarım korkusu... Düşünsene hafif bir psikopat kocan var velev ki bir bakıyorsun bunun ayarında biri çıkmıs karısını öldürmüs,, bu ister istemez kadını acaba ben hani hareketlerimin ayarını yapmalıyım ki bu da böyle bir şeye dönüşebilir bende yaşayabilirim aynısını korkusu oluyor... Medya bu konuda olumlu değil olumsuz etkiliyor yani... Normalleştiriyor durumu. En basit örneği işte psikopat katil yakalandı (Atalay Filiz) Adamlar polisler bununla selfi yarışına giriştiler... Böyle bir şey var mı arkadaş, onun egosunu kucakladılar yani egosunu yükselttiler... Şiddeti normalleştirdiler yani... Çoğu da masum kadın yani bunların (Öldürdüklerinin). Biri öğretmen. Yazık değimli yani tertemiz bir kadın bu manyak yüzünden öldürüldü...(Dr. Öğrt. Üyesi, 44, Bekar) ...Bence görülen şiddet haberleri normalleştiriliyor. Ne kadar çok görülürse o kadar normalleşiyor. Son yıllarda artık bilemiyorum şu fikrimi paylaşan insanlar var mı var son yıllarda Türk toplumu yani Türkiye sinırları içerisinde ben oldukça ötekileştiğimi düşünüyorum. Beni rahatsız ediyor ama benim baktığım noktadan toplumun geri kalanı için normalleşiyor. Yani ben rahatsız olduğumla kallyorum gibi bir hissiyat içerisindeyim o yüzden. Tabii ki benim gibi rahatsız olan insanlarda vardır. Ama çok azınlık kallyoruz bence geri kalan kısım normalleştiriyor...(Dr. Ögrt. Üyesi, 32, Bekar)

Eğitim seviyesi en yüksek kesim olarak tanımlayabileceğimiz kadın akademisyenlerin kadın hakları ve yapılan yasal düzenlemeler konusunda bakış açıları oldukça önemlidir. Çünkü toplumun elit kadınları olarak görülen bu kesim, diğer kesimlerine örnek teşkil edecek ve düşünceleriyle onları yönlendirecek kanaat önderleri niteliğindedir. $\mathrm{Bu}$ açıdan kategori 3 altında; teorik kurgulama, yüzeysel çalışmalar, kâğıt üzerinde yasa, siyasi boyut kazandırma gibi kavramlaştırmalardan hareketle akademisyenlerin konuya bakışları analiz edilmeye çalışılmıştır. 
Aile ve Sosyal Politikalar Bakanlı̆̆ı'nın kadına yönelik politikalarını kadın akademisyenlerin nasıl anlamlandırdıkları incelendiğinde, araştırmaya katılan evli örneklemlerin hepsinin, bakanlığın kadın politikaları hakkında yeteri kadar bilgilerinin olmadıklarını belirtmeleri düşündürücüdür. Bekâr örneklem incelendiğinde bakanlığın politikalarının daha çok yetersiz bulunması ve siyasi boyut kazandırmanın söz konusu olduğunun BK1, BK2 ve BK5 kodlu örneklemlerin düşüncelerinde şu şekilde ortaya çıktığını söyleyebiliriz: ...Kadın ve çocuklara yönelik bir takım çalışmalar var. Kanunlar var uygulanabilirliği ve onların bakış açısını ben çok şey bulmuyorum. Olayı biraz siyasi boyut kazandırma. Önceki bakanın biraz daha tecavüze uğrayan çocuklara yönelik bakışını bir kereden bir şey olmaz diye ifade etmesi beni çok şaşırtmıştı. Yani yaklaşımları zihniyet olarak bu şekilde ise aksi yönde pek bir şey görmüyorum. Hani olumlu adımlar atıllyormuş gibi ama yeterli bulmuyorum. Uygulamada da çok sıkıntı görüyorum aslında örneğin eşini bir şekilde öldürmüş ya da yaralamış ne bileyim Eskişehir'de geçenlerde bir kadına evlenecekler miymiş, nişanlısı mıymış kadına bayağı bir şiddet uygulamış. Kadın hastaneye kaldıılmış, kaç yerinden bıçaklamış kadında mimar sanırım iç mimar çok ciddi zarar görmüş ve hala davaları devam ediyor kadının hayatı karamış işini gücünü takip edemiyor fakat ciddi bir cezada yok bunların karşılığında. Siz bir insanın hayatını yok edebiliyorsunuz ama bunun karşıllğında böyle basit cezalarla evet yasalar var ama yeterli değil. Bunların tartışılması gerekiyor. İște bu konularda Aile ve Sosyal Politikalar Bakanlı̆̆ı'nın konuyu gündeme getirip azaltmak için caydırıcı cezalar olmall, bilinçlendirme bilgilendirme çalışmaları olmall. Bunlara pek şahit olmadım belki de ben yeterince takip edemediğim için bilmiyorum. Doğrudan hedef alıp ta suçlamak istemiyorum kimseyi yapllıyorsa da takip edemediğimden benim eksikliğimdir. O yüzden var mı bilmiyorum. Ama olması gereken insanları doğrudan medyadan bilgilendirmek vs. yerine bilinçlendirme amaçlı her yerde artık toplantı salonları vs. var aslında özellikle biraz daha varoş olabilecek eğitim seviyesi düşük mesleki eğitim seviyesi düşük kadınlara ev hanımlarından başlayarak bilgilendirsinler...(Doçent, 40, Bekar) ...Ben o konuda çok ciddi çalışıldığını düşünmüyorum... Mesela Fatma şahin zamanında bakanken gördüğüm en hassas, en çalışkan bakandı ama sonrasında gelenler bana o kadar çalışıyormuş gibi gelmedi yani. Yeterli düzeyde çalışma olsa zaten en basit benim duyduğum bu tecavüz olayı olmazdi. Kadıncağız evli kocası tarafindan bunu yaşlyor ve hiçbir yere gidemiyor. Bu bakanlık zaten çalışsa burada ya da başka bir yerde bu kadında mağdur olmaz diye düşünüyorum yani... Adli tıbba gidip raporda allyor bir çözümde olur ama yok... Bunların bir çözüm olduğunu, kadınlarında dü̧̈ündüğ̈̈nü zannetmiyorum yani... Bu kadar olaya rağmen ne oldu bak işte. Bence çözüm olarak toplumdaki kadınlara bakanlık yapacă̆ sigara içmeyin diye yapılan kamu spotlarını kadınların çaresizlikleri içinde yapılmalı ve kadınlara güven verecek şeyler yapılmalı...Erkeklere de böyle şiddet uygulayanlara çok ciddi cezalar verilmeli ki hani bu olay sona ersin yani...Yoksa Türkiye de bu kadar kadının yani....Sonuçta adamda hapse giriyor kadın ölüyor, çocukları rezil rüsva oluyor...Bunların bir şekilde eğitilmeli...ve kadınlara zarar verildiği zaman ailesinin temeline bomba koyacağını adamın beynine kazınması lazım...Çünkü ailesi çoluğu çocuğu her şey bitecek yani...Bu şeyi ayakta tutan kadın ve bunun alglamalarl lazım erkeklerin...(Dr. Öğrt. Üyesi, 44, Bekar) ...Bakanlığın bir şey yaptı̆̆ını sanmıyorum. Ya da işe yaramıyor yani yapıyormuş gibi görünüp yapmıyor sanki. Toplumsal basklya dayanamıyor, kadın dernekleri örgütleri bayağı yükleniyorlar. Zaman zaman yürüyüşler gösteriler yapıyorlar ama sanmıyorum yani onlarında bakış açısı belli sonuçta hükümetin. Adamlar ne diyorlar çeyiz hesabı falan açtırın. Ë̆itim hesabı açtırın demiyor da kılar doğunca hemen çeyiz hesabı açtırın. Bu zihniyetten ne bekleyebiliriz ki...(Dr. Ögrt. Üyesi, 42, Bekar) 

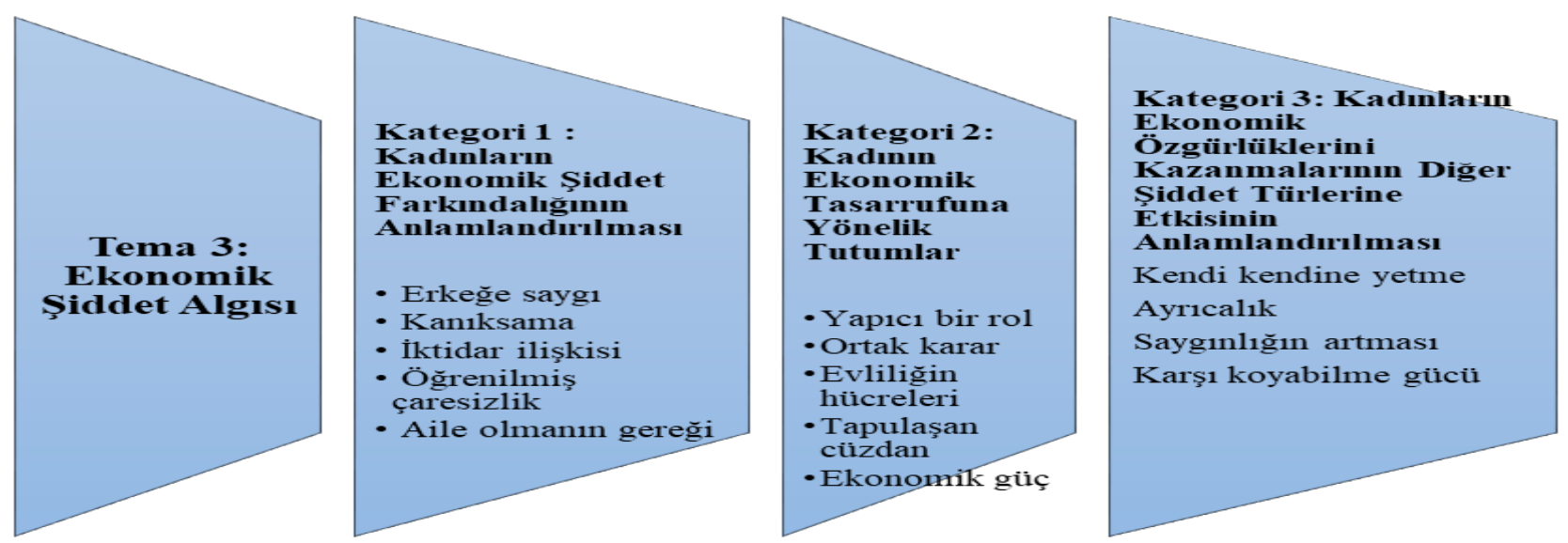

Şekil 4. Tema 3 ekonomik şiddet algısı

Tema 3 başlığı altında ekonomik şiddet algısı 3 farklı kategoride kavramsallaştırılmaya çalışılmıştır. İlk kategoride toplumsal yaşamda kadınların ekonomik şiddet farkındalığının ne seviyede olduğu akademisyenlerin gözünden analiz edilmeye çalışılmıştır. İkinci kategoride, kadınların ekonomik tasarruflarına yönelik tutumlarının nasıl olduğu ve ev içerisinde ekonomik tasarruf hakkının toplumsal cinsiyet bağlamında kimde olması gerektiği gerekçeleriyle ele alınmıştır. Son olarak tema 3 başlığı altında kadınların ekonomik özgürlükleri ile diğer şiddet türlerinin azalıp artmasında nasıl bir ilişkinin olduğu sorgulanmıştır.

Kategori 1 başlığı altında kadın akademisyenlerin gözünden, kadınların ekonomik şiddete uğrama durumları, ekonomik şiddete maruz kalıp kalmadıklarından kadınların farkındalıkları ve kadınların ekonomik şiddeti kanıksama durumları anlamlandırılmaya çalışılmıştır. Bu açıdan kategori 1 altında; erkeğe saygı, kanıksama, iktidar ilişkisi, öğrenilmiş çaresizlik ve aile olmanın gereği gibi kavramlaştırmalardan çıkarımlar ortaya konulmaya çalışılmıştır.

Ekonomik kazancı olan kadınların eşleri tarafından ekonomik şiddete maruz bırakıldığını söyleyen BK3 kodlu örnekleme göre, çalışan kadınlara oranla çalışmayan kadınların çok daha fazla ekonomik şiddete maruz kalmaları söz konusudur. Geleneksel cinsiyet rollerinin toplumumuzda çok yoğun olarak yaşandığını ifade eden BK3, birçok kadınında çalışmasına rağmen, evdeki sorumluluklarını yerine getirmek adına aile olmanın gereği düşüncesiyle, işten ayrılmak zorunda bıraktırıldığını da şu sözleriyle ifade etmektedir:...Ekonomik şiddete kadınlar çok fazla uğruyor. Kadın çalışsın çalışmasın erkekler bunu bizim bütçemiz deyip hâkimiyeti, kredi kartlarını da kendisi alıyor. Ama bunu çalışmayan kadın daha çok yaşıyor. Ama kadın evde çalışıyor erkek bunun farkında değil, devletimizde o anlamda kadına sahip çıkmıyor. Okumayan evde çok olan kadın var onların yaşadiğl şiddet bence çok kötü bir şiddet. Ben çalışırken çocuk bakmak zorunda olup işinden ayrılan kadın arkadaşlarımı yakinen gözlemliyorum birçok şey onlar açısından eksik ama aile olmanın temeli olarak görülüyor. Eşleri de çalışıyor ama kadınlar o konuda yok gibi. Istediğini alıp yapamıyor ama aslında ikisinin çocuklarına baklyorlar. Bu tür durumlarda bir ayakkabı alırken bile kadın harcamaları çok daha düşünüyor. Buna yakından şahit oluyorum ...(Dr. Öğrt. Üyesi, 43, Bekar)

Kadının çalışıp çalışmaması, çok eğitimli olup olmamasının çok fazla fark etmediğini, karar verme noktasında iktidar ilişkisinin her zaman erkekte olduğunu ifade eden BK4 kodlu örnekleme göre, kadının ekonomik şiddete çok fazla uğraması söz konusudur. Bu durumu izah etmeye çalışırken, kadın kolluk kuvvetlerinin bile toplumumuzda kendi parasında tasarruf hakkı olmadığını şöyle ifade etmektedir:...Kesinlikle ekonomik şiddete toplumumuzda çok fazla kadınlar ekonomik anlamda şiddete uğruyor. Şimdi burada herkes polislerde buna dâhil olmakla birlikte, polis memurlarına baktı̆̆ımız zaman bir araştırma vardı. Polis memuru kadınlar bile maaş kartlarını kocalarına veriyormuş. Yani şimdi bu çok normal bir şey değil. Benim annem 60 yaşında bir kadın babamda çok teknolojiden anllyor değil ama mesela o da verir sen çek falan, sevgi şefkat göstergesi olarak anlaşllabilir ama bu da ekonomik olarak şiddetin bir göstergesi... Aslında yani karar vermenin genelde erkekte olduğunu görüyoruz. İster kadın çalışıyor olsun ister çalışmıyor olsun, çok eğitimli olsun olmasın, aslında çokta fark etmiyor gibi geliyor bana...(Dr. Ögrt. Üyesi, 42, Bekar) 
Toplumda kadının kesinlikle ekonomik şiddete uğradığını düşünen BK6 kodlu örneklemle aynı düşünceleri paylaşan BK2 kodlu örnekleme göre, bu durum öğrenilmiş bir çaresizlik olarak değerlendirilmelidir. Ona göre, iktidar ilişkisinin geleneksel değerlere göre kültürel kodlarımıza derinden işlemesi şu şekildedir: Ekonomik şiddet şöyle ki kültürel değerlerimize işlemiş... Yani kadın mutlaka ekonomik şiddette görüyordur. Çalışan ya da çalışmayan kadın için erkek egemen bir yapı içerisinde öğrenilen ve yapacak bir başka şeyi olmayan bir kusır döngü. Değişmesi çok kolay değil gibi geliyor bana. Bir örnek vereyim size yakınlarda beni çok derinden sarsan. Ankara da bir memur arkadaşla yemeğe gittik. Geçen aybaşıydı çok şaşırdım. İskender yemek için kocasını arayıp İskender yiyebilir miyim dedi. Bunu çok net gördüm ve bundan daha öte bir ekonomik şiddet var mıdır?..(Dr. Ögrt. Üyesi, 44, Bekar)

Kadınların çok fazla ekonomik şiddete uğradıklarını ve bunun eskiden erkeğe saygı olarak göründüğünü şimdi ise kadınların kazandıkları parayı kocasının eline getirip direkt olarak vermeyeceğini savunan EK4 kodlu örnekleme göre, kadının ekonomik kazancının kendi tasarrufu dışında kocası ya da babası tarafından elinden alındığını ve bu durumun kişinin yetiştiği aile ortamına göre değiştiğini şöyle ifade etmektedir:...Tabi uğruyor. Kadını çalıştırıp parasını alan vs. eskiden kadın çalışır ve kazandığı parayı eşinin eline teslim ederdi. Bu o zamanlar bir şiddet olarak düşünülmezdi. Bu erkeğe saygı olarak algılanırdı. Ama şimdi ki toplumda hiçbir kadın çalışıp kazandığ parayl getirip kocasının eline vermez ben görmüyorum. Öyle bir toplumsal yargı kalmadl. Ben istediğim gibi kullanıyorum. Ben Van da 22 genç kızla çalıştım. Arıcılık ögrettik onlara. Bize sordukları şuydu. Ben evlendiğimde kovanımı kocamamı vereceğim. Onların elindeki her türlü mal ya da mülk kocası tarafindan alınıyor. Kazandığ paralarda babaları ya da eşleri tarafindan alınıyor. Halen doğu kesiminde gördüğüm bu eğitim seviyesi yetersiz olan kızların, hatta bir kaçının hiç okuması bile yok ve bunların kazandiğ her kuruş babası ya da eşi tarafindan alınıor ellerinden. Onların çok öyle özgürce harcama şansı olmuyor. Rahatça harcama yetisi olmuyor çok fazla. Yetiştiği aileden kaynaklaniyor...( Dr. Ö̈̆rt. Üyesi, 42, Evli)

Kadının ekonomik tasarrufuna yönelik tutumlar kategorisi altında, iki temel alt kategoriden hareketle bir analiz yapılmıştır. İlk olarak, aile içerisinde ekonomik tasarruf hakkının kimde olması gerektiği ile ilgili bakış açıları değerlendirilmeye çalışılmıştır. İkinci olarak da, akademisyenlerin gözünden, Türkiye'de kadının kendi malında tasarruf hakkının ne kadar olduğu üzerine kavramsallaştırmalar anlamlandırılmaya çalışılmıştır. Bu kategori altında; yapıcı bir rol, ortak karar, evliliğin hücreleri, "tapulaşan cüzdan”, ekonomik güç gibi kavramlaştırmalardan hareketle anlamlandırmalar yapılmaya çalışılmıştır.

Aile içerisinde tasarruf hakkının her iki tarafta da olması gerektiğini savunan BK4 kodlu örneklemin ifadelerinde, kadına sürekli tasarruf eden, yapan ve yapıcı olan bir rol verildiğini, erkeğin ise daha çok kendi keyfine göre harcamalar yaptığını kendi ailesinden örnekler vererekten şöyle ifade etmektedir: ...Iki tarafin elinde olmalı tabii ki ama burada hep kadını bir rol veriliyor, tasarruf eden koruyan, yapan yapıcı bir rol veriliyor. Erkek mesela çok kendi keyfine göre harcamalar yaparken, dışarda daha çok vakit geçirdiği için yemek, işte ne bileyim arkadaşlarla buluşma, sosyal zaman harcama geçirme anlamında, çok daha fazla dışarda zaman geçiriyor. Kendisine daha çok harcama yapıyor ama kadınların böyle olmadığını görüyoruz. Yani bu her kesimde böyle yani. Mutfak harcamaları normal şeyler her şey yani. Ben kendi ailemden de görüyorum. Şimdi babam kendi keyfine göre bir şeyler allyor ediyor ama annem evi düşünüyor. Bunlar tabi kötü şeyler ama kişinin üstüne başına kişisel eşyalar tabi bunları kadınlar daha az harcıyor. Kendi paralarını kazansalar bile öyle olabiliyor. Burada biraz sinıfsal şeye bakmak lazım. Üst sinıflarda böyle bir şey söyleyemeyiz ama daha böyle dar ve orta gelirli ailelerde kadınların evin giderleriyle kendi giderlerini ya da ihtiyaçlarını ortaklaştırdı̆̆ harcamalarını görüyoruz...( Dr. Öğrt. Üyesi, 42, Bekar)

BK4 kodlu örneklem gibi aile içerisinde tasarruf hakkının karşılıklı olmasını savunan EK4, EK5, BK1, BK3, BK5, BK6 ve BK7 kodlu örneklemler konuyu kendi yaşantılarından ya da çevrelerinde gördüğü yaşantılardan hareketle, sırasıyla aşağıdaki gibi ifadelendirmektedirler:...Bence karşılıklı olmalı. Bizim ailemizde bir şey yapılacaksa karşılıklı oturup konuşuyoruz. Ama ben bir şey söylediysem hiçbir şekilde buna karşı çıkış olmuyor. Hatta bana hesabını bile sormaz eşim. Ben bütün maaşımı harcamışsam o şöyle düşünür: gerekiyordur ki harcamıştır. Zaten hesabını sormaz yani niye harcadın, nereye harcadın. Ama tam tersi ben sorarım. Nereye harcadın niye harcadin diye sorarım. Eşim bundan nefret ediyor. Gerekiyordur ki harcamıştır diye düşün der...( Dr. Öğrt. Üyesi, 42, Evli) ...Bizde bende. Ben kendi hesabımda tutuyorum. Bizde derken eşim bu ay bu kadar fazla var al kendi hesabında 
tut kenara koyalım diye veriyor. Karl-koca birlikte olacak doğrusu da o. Evin alışverişini genelde eşim üstleniyor. Ama eşimden ayrı param var mı var. Onun bilmediği param mevcut. Bu da iyi bir şey mi kötü bir şey mi bilmiyorum...( Dr. Ögrt. Üyesi, 39, Evli)...Bir kişinin tek elinde olmamasl gerekiyor. Aile ise aile anne ve baba onlar karar vermeli. Eşler ortak karar vermeli diye düşünüyorum. Biri ben dedim oldu olmamall. Asgari müştereklerde buluşmak diye bir şey vardır ya yani durum ortaya konulmall, gelir budur gider budur ona göre yön verilmeli diye düşünüyorum...(Doçent, 40, Bekâr)...Bence ortak olmalı. O konuda birinde olsun diyemiyorum. Kadın istediğini çok açılama yaparak değil. Çok sıkıntı yaratmıyorsa insanlar birbirine çok açıklama yaparak değil insanların kendisinde olsun tasarruf hakkı. Şuna da katılıyorum kadınlar bazen çok harcamalar yapıyorlar. Alışverişe çok merakl oluyor erkek bazen onu engellemeye çallşlyor. Bence zaman içinde o dengelenmeli iki tarafta tasarruf etmeli. Illişki zaten onu yönlendirir gibi geliyor bana ama ortak olmalı...(Dr. Öğrt. Üyesi, 43, Bekar)...Kişisel olarak benim yetiştiğim ortamda söylersem zaten eşimde bu noktada saygılı bende ona saygllıyım. Herkesin malı kendinedir, herkes kendi malını istediği gibi kullanma hakkına sahiptir. Ha gerektiği zaman fikir sunacă̆ız evliyiz. Gerektiği yerde gerekli müdahaleleri tabii ki yaparız. Ama genel anlamda herkesin kendi malı kendi kullanım hakkına sahiptir diye bir anlayışımı var. Çünkü sonuçta benim mirasım kendi ailemden gelmiş, eşimin mirası kendi ailesinden gelmiş biz birbirimizin hayatına 32 yaşında girmişiz. Sonuçta benim atalarımdan gelmiş bir malı kullanma hakkının bende aynı şekilde onda da ayrlması lazım. Toplumsal olarak biz her şeye karışmaya meraklı olduğumuz için bir kavga yapılırken 10 kişi gider karışır arada da döven dövülenler olur. Biz çok severiz böyle şeylere karışmayı o yüzden bizim kişisel saygıda biraz sıkıntılarımız var. Insanların kendi çizgileri yok. Özgürlük alanları bırakmıyoruz insanlara. Her şeylerine karışlyoruz. Her şey hakkında söyleyecek bir lafimız vardır. Türkiye toplumunda genel bir algıdır bu yani bu senin kişisel alanındır. Burası senin özgürlük alanındır diye bir alanımız ne yazık ki yok kişisel anlamda. Aynı şey mallar içinde geçerli artık evlendik ya sen ben yok. Var aslında ama yok genel anlamda erkeklerin diktaları noktasında psikolojik baskı ile kadın dirense bile erkek zaman içerisinde kendi bildiğine çevirir ve kendi bildiğine getirir. Yani nikâh, evlenme cüzdanını tapu olarak gören bir toplumuz biz. Yani artık tapun bende diye gören bir toplumda malın tapusu da erkeğe geçiyor diye gören bir toplum var maalesef...(Doçent, 38, Evli)

Farklı toplumlarda kadınların harcama yetisi olmadığını belirten EK4 kodlu örneklem, bizim toplumumuzda da bu şanslarının olmamasının arkasında geleneksel değer yargılarının etkisinin olduğunu ifade etmektedir. Ona göre, ailenin geleneksel değerlerine bağlı olarak, kız çocuklarının okutulmaması düşüncesi, kadınların tasarruf haklarının da ellerinden alınmasına sebebiyet verdiğini şu sözleriyle ifade etmektedir: ...Birçok toplumda istediği gibi harcama yetkisi yok kızların. Bizde de aynı. Bu şanslarının olmamasının nedeni de aile. Okutmamışlar kızlarını. Kız çocuğu okumaz prensibi halen geçerli olduğu için ikinci sinıf görülmekteler. Bu şekilde yetişen kızlarda aynı şekilde nesiller yetiştirmekte, hatta bunu bir şiddet olarak ta görmemekteler çoğunlukla...(Dr. Öğrt. Üyesi, 42, Evli) Ek4'ün ifade ettiği geleneksel değerlerle yetişen kadınların farkında olmadan erkeğe ekonomik tasarruflarını verdikleri düşüncesini, EK6 kodlu örneklemin ifadelerinde somut olarak görmek mümkündür. Ona göre, erkeğin kadının önceden getirdiğ $i$ mal varlı̆̆ geliştirmesinden ziyade, kadının erkeğe o alanı farkında olmadan açtığını şöyle ifade etmektedir:...Kadının altınları diye bir mesela var bizim toplumumuzda ya da kendi ailemden düşünüyorum kendi annemin sahip olduğu mülklerde babam bizzat hak talep etmiyor ama annem babama bunun hakkını sunuyor. Eşitsizlik tam da kadının arabasını adam kullanıyor kadının evini arsasını adam kullanıyorsa orda eşitsizlik başlıyor. Ne yazık ki bu toplumda eşitsizlik geleneklerle gelen ve kadının farkında olmadığı bir şey. Kendi kendine de uyguluyor bunu kadın... Dişli bir kadın olduğunuzda kullanma şansınız artar bu toplumda 100 kadından çok küçük bir kesimi bunu yapabiliyor bence...( Dr. Ö̈rt. Üyesi, 33, Evli)

Kadının ekonomik özgürlügünün olması gerektiği noktasında ortak bir bakış açısı sunan örneklemin, kadınların ekonomik özgürlüklerini kazanmalarının diğer şiddet türlerinin azalmasında ya da artmasında ne tür etkisi olduğu kategori 3 başlığı altında incelenmiştir. Bu kategori altında; kendi kendine yetme, ayrıcalık, saygınlığın artması, karşı koyabilme gücü gibi ortak kavramlardan hareketle analizler yapılmaya çalışılmıştır.

Kadının ekonomik özgürlüğü olduğu takdirde kendi kendine yetebileceğini savunan EK3 kodlu örnekleme göre, diğger şiddet türlerinin de bir nebze azalması söz konusudur. Ona göre, en kötü şiddet durumunda bile ekonomik özgürlüğü olan bir kadının, kendi haklarını daha iyi bir şekilde 
savunabileceğini şöyle ifade etmektedir: ...Biraz daha azalıyordur. Çünkü ekonomik özgürlüğ̈̈nüz var. Oldukça önemli bir şey. Kendi kendinize yetersiniz. Dolaylsıyla kendi kendinize yetemezseniz bile psikolojik tedavi görme imkânına sahip olursunuz. Bir avukatla görüşme imkânına sahip olursunuz. Dolayısıyla kendi haklarınızı daha iyi bir şekilde savunabilirsiniz diye düşünüyorum. Yani şiddete maruz kalmamak için...(Doçent, 37, Evli)

EK3 kodlu örneklem gibi ekonomik gücün önemli olduğunu savunan EK4 kodlu örnekleme göre, ekonomik gücü olmayan kadınların bir şekilde kocalarına bağımlı kaldıkları ve ister istemez şiddetin çeşitlerine farklı boyutlarda uğradıklarını ifade etmektedir. Ona göre, çocuğa endeksli bir bakış açısının toplumumuzda egemen olmasının, kadınların ekonomik özgürlüklerinden mahrum kalmalarına da sebebiyet vermektedir. EK4 kodlu örneklem, bu durumu kendi ailesinden örneklerle şu şekilde ifade etmektedir. ...Ekonomik gücün önemli olduğunu düşünüyorum. Kadın ayakta durduğunda diğer şiddet çeşitlerine uğrasa da karşı koyabilir. Bazen evlilik olunca kadının kendine biçtiği anlam da kayboluyor. Ablam çalışıyordu mesela ama eşi evlendikten sonra çalışmasını istemedi. Çok güzel bir işi ve çok rahat kariyer yapabileceği, yükselebileceği bir konumdayken çalışmayacaksın dedi. Ben bunu ablamın nasıl kabul ettiğine de anlam veremiyorum. Zaten çok ekonomik özgürlükleri de yok ki kendi yağında kavrulmaya çalışan bir aile. Dolayısıyla bana söylemese de şiddet gördüğünü biliyorum, duyuyorum bana söylemese de. Hem ekonomik nedenle olduğunu düşünüyorum hem de ne yapsin ki. Gitse bir yerde kendi başına ayakta durabileceği bir getirisi yok. Ayrıca çocuklarını düşünüyor insanlar bu da önemli bir faktör. Evlenenlerin çocuklarl olduktan sonra hep çocuğa endeksli oluyorlar...(Dr. Ögrt. Üyesi, 42, Evli)

Diğer şiddet türlerinin ekonomik özgürlük kazanıldığı taktirde azalmasını, kadının daha sağlam yere basmasıyla açıklamaya çalışan EK5 kodlu örnekleme göre, şiddetin azalmasında erkeğin tutumunun ve aile yapısının önemli olduğunu şöyle ifade etmektedir: ...Şiddeti azaltır çünkü kadın daha sağlam yere baslyordur. $O$ zaman o çok ince bir şey tam olarak bir şey söyleyemiyorum. Bu tamamen aileye özgü, karşısındaki erkeğe özgü bir şey. Ĕ̆itim ve psikolojisine bă̆ll. Yani kadın ayakta durduğunda karşısındaki bundan memnun mu oluyor. Yoksa korkuyor mu? Ĕ̆er memnun oluyorsa aile açııından güzel bir şey ama adam korkuyorsa o zaman o şiddetlerin artmasına sebeptir. Ama kadının özgüveni birçok açıdan kadına şiddete karşı koyma gücü verir...( Dr. Öğrt. Üyesi, 39, Evli)

Şiddetin çeşitlerinin birbirleriyle ilişkili olduğunu savunan EK6 kodlu örnekleme göre, kadının ekonomik özgürlüğünün olması ve onun üzerinde tasarruf hakkı olduğu taktirde, erkeğinde ona sayg1 duymasına sebebiyet verdiğini şu sözleriyle ifade etmektedir:...Her şeyden önce şiddet dediğiniz şeyin tezahürleri birbiriyle ilişkili. Çünkü kaynaklandı̆̆ yer aynı yer aynı yerden besleniyor ve çıkıyor. Bir kadın ve erkeğin eşit iki birey olduğunu kanıksayabildiğimiz noktada hepsi azalır. Kadının ekonomik özgürlüğ̈̈ var örneğin arabası varsa onu satabildiği taktirde erkek şunu bilecek bu kadın bir birey ben buna saygı duymalıyım bu otomatik olarak örneğin cinsel saygıyı da getirecek ya da sosyal saygıyı da getirecek beraberinde... (Dr. Ögrt. Üyesi, 32, Evli)

EK6 kodlu örneklem gibi BK2 kodlu örneklemde kadının ekonomik özgürlüğünün olmasının erkeğin bakış açısını değiştireceğini savunmaktadır. Bu durumu somut olarak bir erkek akademisyen üzerinden şu sözleriyle ifade etmektedir: ...Erkekler içinde kadının para kazanması önemli artık... Bunu da ben çevrem den duydum. Bak burada çok yakın bir ögretim üyesi erkekten duydum. Ben dedi evlendim ama (eşi çalışmıyor bu arada) buradan bir yardımcı doçentle evlenseydim cebime 8 bin lira para girecekti ve bu batıdan gelmiş bir hoca bunu söylüyorsa tabii ki kadının para kazanması çok önemli... Kadın bir aktiviteye gitmiyor gidemiyor çünkü neden gidemiyor adam istemiyor çünkü para harcayacak diye... Çıkartmıyor sağa sola. Kendi spor salonuna gidiyor eşinin hiçbir aktiviteye katılmasına müsaade etmiyor... Çünkü kadın hem çalışmıyor hem para kazamıyor bide üstüne bunun parasını harcayacak. Yok öyle bir şey... Erkekler gerçekten en okumuş dediğimiz insanlar bile para konusu olduğu zaman... Ben eminim eşi 2 buçuk milyar maaş alıyor olsa o kadına bakışı falanda değişir. Dĭger şiddet türleri örneğin psikolojik, ekonomik şiddet ortadan kalkar ... ( Dr. Öğrt. Üyesi, 44, Bekar)

Ekonomik özgürlügün kazanılması kadının kendini daha güçlü hissetmesine ve ikinci bir şahsın kadını ezmesine izin vermeyeceğini, diğer şiddet türlerinin de kesin olarak azalacağını savunan EK7 kodlu örneklem, kadının şiddetin önünü kesebileceğini şu sözleriyle ifade etmektedir: ...Bence şiddet kesinlikle azalır. Çünkü ister istemez daha güçlü olacak kendini daha güçlü hissedecek ve ikinci bir şahsa kendini daha fazla ezdirmemiş olacak eşine ya da ailesine ve dolayısıla bu da eşinin davranışlarını da değiştirecek. Ha böyle olmayanda mutlaka vardır. Daha çok zıtlaşma vb. şekilde de 
tartışmalar oluşabiliyor. Bence oran olarak baktı̆̆ımızda daha da azalacaktır. En basitinden şiddet olsa bile çok rahat tamam deyip o şiddete maruz kalmayı kesebilecek, terk edebilecek, uzaklaşabilecektir...( Dr. Ögrt. Üyesi, 30, Evli)

Toplumun aile bütünlüğünü korumak için kadına büyük görevler verdiğini savunan EK1 kodlu örnekleme göre, geleneksel değer yargılarının etkisinin fazla olduğu bir toplumda yaşamaktayız. Kadınların kendi ayakları üzerinde durmaları gerektiğini savunan EK1 kodlu örneklem, özgüvenin artmasında ve ekonomik özgürlüğün artmasında bu durumun çok etkili olduğunu ve şiddetin önlenmesinde etkili olduğunu şu sözleriyle ifade etmektedir: ...Örneğin çoluk çocuk var anne bir şekilde evi döndürmeye çalışıyor, baba hovardalık ediyor, aileye bakmıyor falan filan. Ne yapar orada kadın tamamen çaresizlik içinde. Sadece kendini değil çocuklarını da düşünmek ve o aileyi götürmek zorunda. Bizim toplumumuzda boşanmalarda çok rahat bakılan şeyler değil. Kendi özgürlüğ̈̈, ayakları üzerinde durabilen biri olsa belki bunu çok rahat kendi hayatını da çizebilir. Kendine bir kere özgüveni gelir. Toplumda bir kişinin kendine özgüveni geldiği zaman bence o geleceğini çizebilir. Kendine güveni varsa ekonomik özgürlükte kazanabilir. Çünkü bazı ailelere baklyorsun işe sokmaya çalışlyorsun girmek istemez özgüveni yok. Ben bunu yapabilir miyim? Özgüveni olmayan insan bir işe de giremez ekonomik özgürlükte kazanamaz. Şiddete karşıda duramaz...(Profesör, 47, Evli)

\section{TARTIŞMA VE SONUÇ}

Modernleşmeye bağlı olarak yaşam kalitesinin artmasıyla birlikte, toplumlarda kadına yönelik şiddetin azalması beklenirken, her geçen gün kadına yönelik şiddetin farklı boyutlarının ortaya çıkması söz konusudur. Kadına yönelik şiddetin temelleri araştırıldığında biyolojik ve sosyal etmenlerin farklı şekillerde etkili olduğu literatür incelemesinde elde edilmiştir (Freedman at all, 1993: 239; Bilgin, 2006: 279; Kılıç, 2016: 22). Tarihsel süreçte kadına yönelik şiddet olgusuna yönelik birçok kurumsal bakış açısı ortaya konulmakla birlikte, hepsinin kendince tutarlı yönlerinin olduğunu söylemek mümkündür.

Elde edilen veriler ışığında, kadın akademisyenlerin, kadınların çalışmasına yönelik toplumun algısının nasıl şekillendiğine ilişkin görüşlerinin öncelikli olarak sorgulanması gereklidir. Medeni durum farklılığ 1 gözetmeksizin akademisyenlerin toplumda geçmiş dönemlere göre, kadınların çalışmasına yönelik pozitif tutumların daha etken olduğunu ortaya koymaları söz konusudur. Günümüzde kadınların iş alanında daha çok görüldügünü ve geçmişe oranla daha çok desteklendiklerini savunan akademisyenlere göre, geleneksel değer yargılarının toplumsal yapıda etken olduğunu ve bu geleneksel değer yargılarının hâkimiyetinin (erkeğin) eğitim ve mesleksel statüyle ilişkisinin olmadığı, kültürel ve sosyal sermayenin toplumda bu değer yargılarına göre şekillenmesinde kadına yüklenen öncelikli fonksiyonun çocuk bakmak ve ev işlerini yapmak olarak görülmesinden kaynaklandığı savunulmaktadır. Bu açıdan kadın akademisyenlerin çok fazla tasvip etmemelerine rağmen, toplumda kadının çalışmasına yönelik genel algısının ikili rol kuramının hipotezlerine göre şekillendiğini söylemek yanlış olmaz.

Akademisyenler tarafından, toplumda yeterince kadının çalışmadığı için kadın statüsünün her zaman ikinci plana atıldığını savunan bir görüşün hâkimiyeti GK7 kodlu akademisyenin "Ne yazık ki çalışan kadın oranı oldukça düşük ülkemizde. Elbette bu durumun arkasında geleneksel cinsiyet faktörleri bulunmakta. Bu sebeple ikinci planda kalan kadın sayginlı̆̆ tam elde edemiyor." söyleminden ve diğer akademisyenlerin benzer söylemlerinden çıkarılmaktadır. Kadın statüsünün ikincil plana atılmasında da toplumsal değer yargısı olarak şekillenen "kadının yeri evidir" düşüncesinin söz konusu olduğunu ve kadına iktidar alanı olarak ev içini uygun gören bir toplum içerisinde yaşadığımızı BK3 kodlu akademisyenin "Toplum açısından bence kadının yeri evidir algısı halen egemen." söyleminden ve EK3, EK5, BK1 ve BK7 gibi akademisyenlerin benzer söylemlerinden çıkarmak mümkündür. Bu yapının iş hayatında da devam ettiğini belirten akademisyenlere göre, kadınların yoğunluklu olarak toplumsal cinsiyet kalıplarına göre şekillenen hizmet sektörü ve niteliksiz işlerde çalışması söz konusudur. Yine kadınların çalıştıkları alanlarda da bazı durumlarda ataerkil yapının egemenliğinin söz konusu olduğu ve ev içinde kadından beklenen rollerin iş yerinde de yeniden üretilmesinin desteklendiği durumların olduğu fikri cinsiyetçi rol toplumsallaşması kuramının görüşlerini desteklenmektedir. Kadının iş hayatına katılmasıyla ilgili olarak bölgesel farklılıkların, eğitim seviyesinin hatta sosyal sınıf farklılıkları gibi farklı parametrelerin yaşadığımız toplumda etken olduğunu akademisyenler savunmaktadır. Örneğin alt sınıfa mensup erkeklerin kadının çalışmamasını 
prestijli bir sosyal statü unsuru olarak görmelerine rağmen bu algının orta ve üst sinıflara doğru çıkıldıkça kırıldığını savunan ifadelerin belirginleştiği söylenebilir.

Toplumun kadının çalışmasına yönelik genel yargısı tespit edildikten sonra araştırmaya katılan kadın akademisyenlerin, kadının çalışmasına yönelik algıları değerlendirildiğinde, akademisyenlerin bütüncül bir bakış açısıyla kadınların iş hayatına katılmalarını destekleyici ifadeler ortaya koymaları kuramsal açıdan feminist yaklaşımla paralellik göstermektedir. Akademisyenlerin bu bakış açısını destekleyen düşüncelerini; kadınların eğitim seviyesi yükseldikçe muhakkak çalışması gerektiğini, birçok şeyden fedakârlık verdiğini ve kadının çalışmasının ev hayatını pozitif anlamda düzenleyeceğini söylemlerden hareketle ifadelendirmek söz konusudur.

Ev hayatının pozitif anlamda düzenlenmesi noktasında erkeğin kadına bakış açışının ve yaklaşımının değişmesinde, ciddi bir eşitsizliğin önüne geçmede, kadının çalışmasının etken bir faktör olduğunu destekleyen görüşler etkendir (Kılıç, 2015: 45). Çalışmadığı taktirde kadının ekonomik ve sosyal güvencesinin söz konusu olmadığını, geleneksel değer yargılarını destekleyen "pasif bir tip" olarak var olan ve sürekli fedakârlık yapmak zorunda kalan bir kadın profilinin toplumda egemen olacağını destekleyen söylemler söz konusudur. Ayrıca kadının çalışmasının "güçlü durmak" ve "sosyal bir varlık" olmak adına önemli olduğunu destekleyen görüşlerin, kadının ev dışında üretimde yer almadığı takdirde kişisel bakımlarına bile yeterince önem göstermediğini ve en sonunda farkında olmadan kendine yabanc1laşan bir insan tipolojisinin şekillendiğini (EK5, EK7, BK1, BK2, BK4, BK5) ifade eden görüşlerin hâkimiyeti de liberal feminist bakış açısının akademik düşüncede etken olduğunu göstermektedir. Liberal feminist bakışı destekler nitelikte belirtilen negatifliklerin söz konusu olmaması, mikro seviyede ev içinin yeniden inşası ve makro seviyede toplumun gelişmesi açısından kadının çalışması gerektiğini ve kadının çalışma tasarrufunun dışsal unsurlardan ziyade kişinin kendi elinde olması gerektiğini akademisyenler savunmaktadırlar.

Kadınların iş hayatında aktif rol almaları gerektiğini ve ev dışında daha fazla var olmalarını savunan düşüncelerin yanında ülkemizde kadın akademisyenlerin oranını değerlendirme noktasında farklılıkların ön plana çıktığını söylemek gerekir. Literatürde verilen bilginin aksine akademisyenlerin çoğunluğu kadın akademisyenlerin oranının yetersiz olduğunu savunurken, örneklemin geneli üniversitelerde kadın akademisyenlerin oranından ziyade, kadın yöneticilerin yoksunluğunu dile getirmektedirler.

Kendi üniversitelerinde kadın yönetici açısından şanslı olduklarını ve üniversite kuruluşundan bu yana üç dönemdir kadın rektörlerin bulunduğunu, bununda pozitif etkilerinin çok fazla gözlendiğini akademisyenler ifadelerinde dile getirmektedirler. Ülkemizde diğer üniversiteler söz konusu olduğunda ise yönetici pozisyonunda olan kadın akademisyenlerin sayısının oldukça düşük oranlarda olduğunu, 1lımlı ve şeffaf bir yönetim için bu sayıların arttırılması gerektiğini belirtmeleri önemlidir.

Kadın akademisyenlerin karşılaştıkları güçlükleri de dile getiren akademisyenler, genellikle yurt dışından örnekler vererek kadın akademisyenlere pozitif ayrımcılık yapılması gerektiğini çünkü evli akademisyen kadınların, ev içi rollerinin de akademik çalışmaların önüne ket vurduğunu ve bu durumunda kadın akademisyen oranını negatif etkilediğini dile getirmektedirler. Elbette bu tür tespitlerin daha çok EK5 gibi evli ve çocuklu akademisyenler tarafından öncellendiğini söylemekte de fayda vardır. Ayrıca kadın akademisyen oranının ülkemizde diğer sektörlerdeki kadın istihdam oranlarından yüksek olduğunu ortak bakış açılarından hareketle belirtmekte gereklidir. Ama diğer örneklemlerin söylediklerinden farklı olarak EK1 kodlu akademisyenin "...hedefimiz nicelik midir? Bilmiyorum bir meslekte illa kadın olması gerekmiyor ya da bu erkek egemen bir meslektir gibi yaklaşım yanlış. Kadın akademisyen oranı \% 70, erkek akademisyen oranı \% 30 olunca mi yeterli olacak. Neye göre yeterli yani kıstasımız ne?" gibi söylemlerinden hareketle, akademinin bir istihdam alanı olarak gösterilmemesinin, akademik alanların bilimsellik kaygısı taşıması gerektiği ve bilim dalında illa kadın sayısının arttırılmasından ziyade "yetkinliğe" bağlı olarak kadın ve erkek akademisyenlerin oranının şekillenmesini savunan görüşün etken paradigma olması gerektiğini desteklemek oldukça anlamlıdır.

Kadınların toplumsal yaşamda iş alanına katılması hususunda kavramlaştırmalar netleştirildikten sonra, kadına yönelik şiddet noktasında araştırmaya katılan akademisyenlerin bakış açıları tespit edilmiştir. Akademisyenler, kadına yönelik şiddetin toplumsal yaşamda her zaman olduğunu ve günümüzde de bu durumun devam ettiğini ifade etmişlerdir. Kadına yönelik en çok gözlemlenen şiddet türünün psikolojik şiddet olduğunu dile getiren akademisyenler, bu şiddet türünü fiziksel şiddetin takip ettiğini hatta psikolojik şiddetin uzantısı olarak fiziksel şiddetin görüldügünü ifadelendirmişlerdir. Kadına 
yönelik psikolojik şiddete sadece eşler arasında değil toplumun her alanında rastlandığını ve kalıp yargıların toplumsal yaşamda çok fazla görüldüğünü belirtmeleri yapılan bilimsel araştırmaları destekler niteliktedir (Zapf, 1999: 167). Psikolojik şiddetin görülmesinde ise daha çok tahakküm duygusunun etken olduğu ön plana çıkartılırken, bu durumu insan sermayesi kuramında olduğu gibi bir cinsin diğeri üzerinde egemenlik kurmaya çalışması (EK1, EK2, EK5, BK1, BK5) olarak ifadelendirmişlerdir. Eğitim seviyesinin artması ile şiddet arasında negatif bir ilişkinin söz konusu olması ya da olmaması sorgulandığında ise, akademisyenlerin bu durumu izah ederken eğitim ile fiziksel şiddet arasında negatif ilişkinin olduğu, fakat psikolojik şiddeti eğitim seviyesinin artmasının hiçbir şekilde etkilemediği sonucuna varılmıştır.

Kadına yönelik şiddet ve saldırganlığın temelleri araştırıldığında, tarih sahnesinde bahse konu olan biyolojik ve sosyal faktörlerden birinden yana tavır alan araştırmacılar olduğu bilgisine literatürde rastlanmaktadır (Kılıç, 2016). Günümüzde bilim dünyası her iki unsurunda şiddetin ortaya çıkmasında belli ölçütlerde etkili olduğunu kabul etmektedir (Başbakanlık Aile Araştırma Kurumu, 1998: 10). Araştırmada akademisyenler kadına yönelik şiddetin temellerinde kabullenme, doğallaştırma, bastırılma, yetiştiği ortam, öğrenme gibi faktörlerin etkili olduğundan bahsederek, biyolojik temellerden çok sosyal faktörlerin, çevrenin ve medyanın şiddet üzerinde etkili olduğunu savunmaktadir.

Günümüzde kadına yönelik şiddetin çok fazla gözlenmesinde medyanın etkisinin geçmişe oranla fazla olduğu söylenebilir. Yapılan araştırmalarda kadına yönelik şiddet olaylarının geçmişte daha geleneksel ve aile içerisinde çözümlenen ya da çözümlenemeyen bu tür meselelerin mahrem alan diye tabir edilen ev içinde kalması söz konusuydu (Page ve İnce, 2008: 86-87). Şimdi ise modernleşmeye koşut olarak kadının daha fazla sosyal yaşamda yer bulması bu tür şiddet olaylarının görünürlüğünü eskisinden fazla oranlarda medyaya taşımaktadır. Medyada bu tür kadına yönelik şiddet olaylarının toplumsal etkileri araştırıldığında görüşmeye katılan akademisyenlerin çeşitli bakış açıları ortaya koyduklarını söylemek gerekir. İlk olarak akademisyenlerin çoğunluğunun bu tür haberlerin olayları sıradanlaştırdığını, normalleştirdiğini ve ezik karakterler yarattığını savundukları BK6 kodlu akademisyenin "Bence görülen şiddet haberleri normalleştiriliyor. Ne kadar çok görülürse o kadar normalleşiyor. Son yıllarda Türkiye'de ben oldukça ötekileştiğimi düşünüyorum. Beni rahatsız ediyor ama benim baktığım nokta toplumun geri kalanı için normalleşiyor." ifadesindeki gibi diğer akademisyenlerinde benzer söylemlerinden çıkarılmaktadır. Yine bu tür haberlerin çok fazla haber konusu olması, hukuksal anlamda müeyyidelerin yetersiz kalması, her seferinde kadınların negatif olarak benzer durumlara maruz kalması, kadına yönelik şiddetin toplumda duyarsızlaştırılmasına ve kadınların çoğu tarafından kabullenilmesine sebebiyet verdiğini dile getirmektedirler. İkinci bakış açısına göre de, bu tür haberlerin benzer durumdaki diğer erkeklere güç verdiğini ve erkeğe sınırlandırıcı bir etki yaratmadığını dile getiren yaklaşımlar ortaya çıkmaktadır. Bu durumun erkek tarafından toplumda kadına yönelik şiddetin yeniden üretilmesinde etkili olduğunu savunmaktadırlar. Son olarak medyada çıkan haberlerin kamuoyu oluşturma adına önemli olduğunu savunan birkaç akademisyene göre, daha çok bilinçlilik seviyesi yüksek, eğitimli kesimler için bu tür haberlerin önemli olduğu ve ilerleyen zamanlarda bütün halkın bilinçlilik seviyesinin artacağını savunmaktadırlar.

Bilinçlilik seviyesi diğer toplumsal kesimlere göre daha yüksek ve kanaat önderleri olarak görülen kadın akademisyenlerin kadın hakları ve yapılan yasal düzenlemeler konusunda bakış açıları oldukça önemlidir. Bu açıdan Aile ve Sosyal Politikalar Bakanlığı'nın kadına yönelik politikalarını nasıl değerlendirdikleri sorulduğunda, evli akademisyenlerin hepsinin bakanlığın kadına yönelik politikaları hakkında yeteri kadar bilgileri olmadığını belirtmeleri oldukça düşündürücüdür. Bekâr akademisyenler ise bakanlığın politikalarını yetersiz bulmakla birlikte, oldukça siyasal boyut kazanan bir yapı arz ettiğini belirtip bu durumdan hoşnut olmadıklarını, kadın sorunlarına bu şekilde pragmatist çözümlerin bulunmasının mümkün olmayacağını belirtmeleri önemlidir. Hukuksal olarak uygulamalar incelendiğinde akademisyenlerin ortak kanaatinin teorik kurgulamanın iyi olmasına rağmen pratikte sıkıntıların çok fazla olduğu ve bu düzenlemelerin binde bir etki yaptığını dile getirmektedirler.

Kadın akademisyenlerin kadına yönelik şiddetle ilgili bakış açıları analiz edildikten sonra, ekonomik şiddete ilişkin algıları değerlendirilmiştir. İlk olarak toplumsal yaşamda kadınların ekonomik şiddetin ne kadar farkında oldukları sorgulandığında, literatürde yapılan araştırmalarda kadınların 4'te 3'ünün çalışmadığı, en çok ekonomik şiddete maruz kaldıkları ve en az farkında olunan şiddet türünün ekonomik şiddet olduğu tespit edilmiştir (Güler ve ark., 2005: 51-56). Araştırmaya katılan kadın akademisyenlerin ifadelerinden de anlaşılacağı üzere, toplumumuzda çalışan ve çalışmayan kadınların 
ekonomik şiddete maruz kalması söz konusudur. Akademisyenlere göre, çalışmayan kadınların ekonomik şiddete çalışan kadınlara göre çok daha fazla maruz kalmaları söz konusudur. Geleneksel cinsiyet rollerinin etkisinin toplumumuzda çok yaygın olduğunu savunan kadın akademisyenler, kadınların erkeğe saygı, kanıksama, iktidar ilişkisi, öğrenilmiş çaresizlik ve aile olmanın gereği olarak ekonomik şiddeti yoğun olarak yaşadıklarını belirtmektedirler. Ne yazık ki aile olmanın gereği olarak çalışan birçok kadının işten ayrılıp çocuk bakması ya da eşi tarafından ataerkil yapının dayatmacı yapısı tarafından kadının çalışmasının hoş karşılanmaması nedeniyle işten ayrılması aile olmanın gereği olarak görülmektedir. Bu yapı içerisinde kadının çalıșıp çalıșmamasında, kadının çok eğitimli olup olmamasının etkili bir faktör olmadığı, karar verme noktasında iktidar ilişkisinde etken tarafının erkek olduğuna ifadelerinde yer veren akademisyenlere göre, toplumda kadınların kesinlikle ekonomik şiddete uğradığı, bu durumun kadınlar tarafından öğrenilmiş çaresizlik ve kültürel kodlarımıza derinden işlemiş olduğunu ortaya koymaktadırlar.

Kadınların çok fazla ekonomik şiddete uğramalarının eskiden erkeğe saygı olarak görüldüğünü, şimdi ise kadınların kazandıkları parayı direkt olarak erkeğin eline verme durumunun çok fazla olmadığını belirten akademisyenler, kadının ekonomik kazancının kocası ya da babası tarafından elinden alındığının, bu durumun kişinin yetiştiği aile ortamına göre değişiklik gösterdiğini ve ne yazık ki toplumda birçok kadın tarafından ekonomik şiddet olarak algılanmamasında sosyal sermayenin etkisinin oldukça fazla olduğunu belirtmektedirler. Sosyal sermaye ile farkında olmadan sergilenen ekonomik şiddet toplumsal cinsiyet şeması kuramına göre nesiller arasında da gözlenmektedir. Toplumsal algıda geleneksel değerlere göre, anne babanın çocuklarını büyüttükten sonra çocuklardan beklentilerinin çok fazla olduğu ve ekonomik şiddetin çocuklara "bakmakla mükellef" gibi yaklaşımlarla farkında olmadan zorla dayatıldığı da söylenebilir. Akademisyenler, bu tür ifadelerden yola çıkarak her an her yerde çeşitli şekillerde ortaya çıkan ve kanıksanmış olan ekonomik şiddetin toplumda sürekli olarak yeniden üretildiğini savunmaktadırlar.

Toplumsal yaşamda kadına yönelik ekonomik şiddet algısı anlamlandırıldıktan sonra kadın akademisyenlere göre aile içerisinde ekonomik tasarruf hakkının eşlerden hangisinde olması gerektiği sorgulandığında, akademisyenlerin çoğunluğu kendi yaşamlarından da hareketle, ekonomik tasarrufun ortak olmas1 gerektiğini savunmuştur. Sadece EK2, EK3 ve EK7 kodlu akademisyenler ekonomik tasarrufun kadında olması gerektiğini savunmuştur. Ne yazık ki toplumumuzda aile içinde kadına biçilen rolün daha çok tasarruf eden, koruyan, yapan ve yapıcı olan taraf olarak görülmesidir. Sosyal sınıf farkı gözetilerek bu durumun daha çok orta ve alt sınıflarda yaşandığını savunan akademisyenler, ortak tasarruf olmasını evin giderleriyle kadınların kişisel bakım ve harcamalarının ayrı değerlendirilmesi gerektiğini savunmaktadırlar. Bu algının her iki cins tarafından anlamlandırılmasının gerekliliğini dile getirmelerinin yanında kadınların aile içerisinde kendi kendilerine de ekonomik şiddet uygulamamaları gerektiğini savunmaktadırlar. Kadınların toplumda biriktirdikleri kültürel ve sosyal sermayeleri ekonomik durumları iyi olsa da bazen kendisini öte yana atarak hep eşi ve çocuklarına bir şeyler yapmalarında etken olmaktadır. Bu tür algıların değişmesi gerektiğini ve evliliğin hücrelerinin yeniden inşa edilmesinin gerektiğini savunmaları feminist bakış açısını destekler niteliktedir.

Aile içerisinde ekonomik tasarruf algısı izah edilmeye çalışıldıktan sonra Türkiye'de kadının malında tasarruf hakkının olup olmadığı hakkında genel bir bakış açısıyla, akademisyenlere göre kadınların kendi mallarında tasarruf hakları çok az ya da hiç yoktur. Evlilik olgusu söz konusu olduktan sonra erkeğin kadın üzerindeki tahakkümünü, EK2 kodlu akademisyenin ifadesiyle "evlenme cüzdanını tapu olarak gören bir toplum” yapısı içerisinde, kadının kendi malında söz sahibi olması mümkün değildir. Toplumun çoğunluğunun algısının bu düşünce doğrultusunda şekillendiğini, erkeğin direkt kadının malında tasarruf geliştirmekten ziyade, kadının farkında olmadan erkeğe o alanı açtığını belirten akademisyenler bu tür kalıplaşmış geleneksel değer yargılarını eleştirmektedirler.

Kadının ekonomik özgürlüğünün olması gerektiğini sıkı sıkıya savunan akademisyenler göre, kadının ekonomik özgürlügünün olması kendi kendine yetmesine, erkek tarafından saygınlığının artmasına, kadına ayrıcalık yaratmasına ve yeri geldiğinde erkeğe karşı koyabilme gücünün olmasına çok büyük etkendir. Ekonomik gücü olmayan kadınların bir şekilde kocalarına ya da kendi ailesine bağımlı kaldıkları ve bu durumun ister istemez şiddetin çeşitlerine farklı boyutlarda uğramalarında etken olduğunu ortaya koymaktadır. Ekonomik özgürlüğe sahip olduğu takdirde kadına erkeğin yaklaşımının da değişebileceğini ifade eden akademisyenlere göre, diğer şiddet türlerinin azalması da söz konusudur. Ekonomik özgürlüğ̈̈ olmadığında kadının geleneksel değer yargılarını yıkamayacağını savunan 
akademisyenlere göre, kadının sosyalleşmesinde, bilinç düzeyinin artmasında ve özgüven kazanmasında ekonomik özgürlük şarttır.

Son söz olarak, çalışmada elde edilen sonuçlardan hareketle kadına yönelik ekonomik şiddetin azaltılmasında aşağıda belirtilen önerilerin göz önünde bulundurulması gereklidir:

*Kadına yönelik ekonomik şiddet olgusunun Aile ve Sosyal Politikalar Bakanlığı gibi ilgili kurumlar ve sivil toplum örgütleri tarafından toplumda farkındalığının arttırılması için politikalar ve stratejiler geliştirilmelidir.

*İş gücü piyasasında kadınların daha çok çalışmaları ve çalıştırılmaları için yeni planlamalar yapılmalı ve cinsiyet ayırımı gözetilmemelidir.

*Kadın hakları konusundaki yasaların uygulanabilirliğinin arttırılması için ciddi çalışmalar yapilmalidir.

*Toplumsal yaşamda kadınların hukuksal olarak hak ve özgürlüklerini nasıl koruyacakları kamu spotu ya da propaganda yoluyla aktarılmalı ve kadınların hukuki haklarını anlamlandırmaları sağlanmalıdır.

*Medyada kadına yönelik şiddet ile ilgili yayınların haber niteliği taşıması kaygısıyla şiddete teşvik edici nitelikte değil, şiddeti önleyici nitelikte aktırılması için ciddi bilimsel çalışmalar ve denetimler yapılmalıdır.

*Kız çocuklarının örgün eğitimi için çok daha fazla projeler yapılmalıdır.

* İlgili kamu kurumları tarafından aile içi iletişim, etkin iletişim, hoşgörü, uyum, adalet gibi konularda ailelere sistematik olarak eğitimler verilmelidir.

*Kadın araştırma merkezlerinin sayısı arttırılarak konuyla ilgili çok boyutlu akademik çalışmaların yapılmas1 gereklidir.

\section{KAYNAKÇA}

Acker, J. (1992). From Sex Roles to Gendered Institutions. Contemporary Sociology, 21(5), 565-569.

Adaçay, R. F. ve Güney, G. (2012). Kadına Yönelik Ekonomik Şiddet, Uluslararası Katılımlı Kadına ve Çocuğa Karşı Şiddet Sempozyumu, s:312-328, 27-28 Nisan 2012, Ankara.

Akın, A.; Üner, S.; Arslan, Ş.; Yıldırım, N.; Aslan, D.; Erdost, T.; Erbaydar, N.; Çiğdem, E.; Coşkun, A. ve Karaca Ö. (2008). Kadının Statüsü ve Sağlığı İle İlgili Gerçekler, T.C. Başbakanlık Kadının Statüsü Genel Müdürlüğü, Ankara .

Aksoy H. H. (2005). Nitel Araştırma Teknikleri. Ankara Üniversitesi Eğitim Bilimleri Enstitüsü, Ankara.

Aktaş, M. A. (2006). Aile İçi Şiddet: Kadının ve Çocuğun Korunması, Elma Yayınevi, Ankara.

Aktaş, G. (2013). Feminist söylemler bağlamında kadın kimliği: Erkek egemen bir toplumda kadın olmak. Journal of Faculty of Letters/Edebiyat Fakültesi Dergisi, 30(1): 53-72.

Arın, T. (1992). İktisat Kuramının Kadın Sorununa Bakışı, Türkiye’de Kadın Olgusu(iç), (Edit: Necla Arat),s.165-182, Say Yayınları, İstanbul.

Bandura, A. (1978). Social learning theory. Journal of Communication, 28(3): 12-29.

Başbakanlık Aile Araştırma Kurumu (1998). Aile İçinde ve Toplumsal Alanda Şiddet, T.C. Başbakanlık Aile Araştırma Kurumu Başkanlığı Yayınları, Yayın No: 133, Ankara.

Bem, S. (1983). Gender schema theory and its implications for child development: raising genderaschematic children in a gender-schematic society. Signs, 8(4), 598-616.

Bilgin, N. (2006), Sosyal Psikolojiye Giris, 6. Bask1, Ege Üniversitesi Yayınları, İzmir.

Ciner, Ö. (2003). Halkla ilişkiler sektöründe cinsiyete dayalı ayrımcılık. Yayınlanmamış Yüksek Lisans Tezi, Ankara Üniversitesi Sosyal Bilimler Enstitüsü. 
Çetin, İ. (2012). Bir Bataklık Olarak Namusun Temizlenmesi Mefhumu, Uluslararası Katılımlı Kadına ve Çocuğa Karşı Şiddet Sempozyumu, Ankara, s:5-11.

Çıkmaz D, N. VM, ve Güler L. (2006). Spor Sponsorluğunda Etik: Alkol ve Sigara Sorun(lu) Mudur? 9. Uluslararası Spor Bilimleri Kongresi, Muğla.

Çınar, E. M. (1994). Unskilled urban migrant women and disguised employment: Home-working women in Istanbul, Turkey. World Development, 22(3), 369-380.

Dedeoğlu, S. (2000). Toplumsal cinsiyet rolleri açısından Türkiye'de aile ve kadın emeği. Toplum ve Bilim, 86, 139-170.

Dedeoğlu, S. (2009). Eşitlik mi ayrımcılık mı? Türkiye'de sosyal devlet, cinsiyet eşitliği politikaları ve kadın istihdamı. Çalışma ve Toplum, 2(21), 41-54.

Dikmen, N. ve Maden, D. (2012). Kadın Akademisyenlerin Görünmeyen Emeği Üzerine Bir Araştırma: Ordu Üniversitesi Örneği, İstanbul Ticaret Üniversitesi Sosyal Bilimler Dergisi, 11(21): 257-288.

Durmaz, Ş. (2016). İşü̈cü Piyasasında Kadınlar ve Karşılaştıkları Engeller, Ahi Evran Üniversitesi Sosyal Bilimler Enstitüsü Dergisi, 2(3):37-60.

Duruoğlu, T. (2007). Emek piyasasında cinsiyetçi ücret artımı: Bursa organize sanayi bölgesinde bir araştırma. Illetişim Kuram ve Araştırma Dergisi, 24: 61-76.

Ekizceleroğlu, R. ve Zeyrekli, S. (2007). Türkiye'de Kadına Yönelik Şiddetin Nedenleri ve Sonuçları. Kadın Çalışmaları Dergisi, 2(4):63-75.

Eşkinat, R. (2012). Türkiye'de Kadına Yönelik Ekonomik Şiddet: Boşanmış Kadınlara Yönelik Araştırma, Uluslararası Katılımlı Kadına ve Çocuğa Karşı Şiddet Sempozyumu, s:329-348, 27-28 Nisan 2012, Ankara.

Eşkinat, R. (2013). Türkiye'de Kadına Yönelik Ekonomik Şiddet: Boşanmış Kadınlara Yönelik Araştırma, Dumlupınar Üniversitesi Sosyal Bilimler Dergisi, 37: 289-302.

Fraim, N.L. (2012). Kadına Yönelik Fiziksel Şiddetin Biyopsikososyal Sonuçları, Uluslararası Katılımlı Kadına ve Çocuğa Karşı Şiddet Sempozyumu, Ankara, s:1-4.

Freedman, L. J.; Sears, O. D. ve Carlsmith T. M. (1993), Sosyal Psikoloji, Çev: Ali Dönmez, 3. Bask1, İmge Kitabevi, Ankara.

Güler, N.; Tel, H. ve Tuncay, Ö. F. (2005). Kadının Aile İçinde Yaşanan Şiddete Bakışı, Cumhuriyet Üniversitesi Tıp Fakültesi Dergisi, 27(2):51-56.

Güriz, A. (2011). Feminizm Postmodernizm ve Hukuk, 2. Baskı, Phoenix Yayınları, Ankara.

Gürkan, C. Ö. ve Coşar, F. (2009). Ekonomik Şiddetin Kadın Yaşamındaki Etkileri, Maltepe Üniversitesi Hemşirelik Bilim ve Sanatı Dergisi 2(3): 124 - 129.

Hill, C.; Corbett, C. and St. Rose, A. (2010) Why So Few? Women in Science, Technology, Engineering and Mathematics. Washington: American of University Women.

Işık, E. ve Serdaroğlu, U. (2015). Kadın emeği: Feminist iktisadın yol haritası üzerinden bir okuma. Mesleki Să̆llk ve Güvenlik Dergisi, 15(56), 6-14.

Işık, S. N. (2007). Türkiye'de Kadın Hareketi ve Kadına Yönelik Ekonomik Şiddet. Aile İçi Şiddet, Kadın Çalışmaları Dergisi, C.2, (4), s.112-117. 
Kasnakoğlu, Z. ve Dayığlu, M. (1997). Female labor force participation and earnings differentials between genders in Turkey. J. M. Rives ve M. Yousefi (Ed.), Economic dimensions of gender inequality: A global perspective içinde (95-117). Westport, CT: Praeger.

Keskin, Ö. (2012). Kadına Yönelik Psikolojik Şiddetin Boyutlarının Belirlenmesi ve Değişken Durumlara Göre Değerlendirilmesi: Rize İl Örneği, Uluslararası Katılımlı Kadına ve Çocuğa Karşı Şiddet Sempozyumu, Ankara, s:92-108.

K1lıç, D. ve Öztürk, S. (2014). Türkiye'de Kadınların İş Gücüne Katılımı Önündeki Engeller ve Çözüm Önerileri: Bir Ampirik Uygulama, Amme İdaresi Dergisi, 47(1):107-130.

Kılıç, M. (2012). Etnisite ve Spor, Doğu Kütüphanesi Yayınları, İstanbul.

Kılıç, M. (2014). Gençliğin Şiddet Algısı: Düzce İli Örneği. A. Ertuğrul (Ed.), Düzce'de Tarih ve Kültür. (ss.216-224), Bursa: Gaye Kitabevi.

Kılıç, M. (2015). Aile ve Serbest Zaman İlişkisi: Düzce Örneği, Düzce Üniversitesi Sosyal Bilimler Enstitüsü Dergisi, 5(1): 27-49.

Kılıç, M. (2016). Gençlik Şiddet ve Serbest Zaman, Doğu Kütüphanesi Yayınları, İstanbul.

Kocacık, F. ve Gökkaya, B. V. (2005). Türkiye'de Çalışan Kadınlar ve Sorunları, C. Ü. İktisadi ve İdari Bilimler Dergisi, 6(1): 195-219.

Kocadaş, B. ve Kılıç, M. (2012). Düşük Sosyo-Ekonomik Yapıdaki Kadın ve Çocuğun Şiddet Algısı, Uluslararası Katılımlı Kadına ve Çocuğa Karşı Şiddet Sempozyumu, s:349-359, 27-28 Nisan 2012, Ankara

Köse, A. ve Beşer, A. (2007). Kadının Değiştirilebilir Yazgısı "Şiddet". Atatürk Üniversitesi Hemşirelik Yüksekokulu Dergisi. 10(4): 114 -121.

Kuzgun, Y. ve Sevim, A. S. (2004). Kadınların Çalışmasına Karşı Tutum ve Dini Yönelim Arasındaki İlişki, Ankara Üniversitesi Ĕ̈itim Bilimleri Fakültesi Dergisi, 37(1):14-27.

Mutlu, F. (2006). Aile İçi Şiddet Sürecinde Kadına Yönelik Şiddet Üzerine Sosyolojik Bir Araştırma. Yayınlanmamış Yüksek Lisans Tezi, Fırat Üniversitesi Sosyal Bilimler Enstitüsü, Elazı̆g.

Nicholson, L. (1994). Interpreting gender. Signs: Journal of Women in Culture and Society, 20(1), 79105.

Ökten, Ş. (2009). Toplumsal cinsiyet ve iktidar: Güneydoğu Anadolu Bölgesi'nin toplumsal cinsiyet düzeni. Uluslararası Sosyal Araştırmalar Dergisi, 2(8), 302-312.

Özdemir, D. ve Tanyıldız, E. Z. (2011). Bilim Kadını Olmak: Bilimsel İşgücünde Kadın ve Cam Tavan. Türkiye Ekonomi Politikaları Araştırma Vakfi. Erişim Tarihi 27 Mart 2016, http://www.tepav.org.tr/upload/files/13039767168.Turkiyede_Bilim_Kadini_Olmak_Bilimsel_Isgucun de_Kadin_ve_Cam_Tavan.pdf.

Özen, S. (2007). İş yerinde Psikolojik Şiddet ve Nedenleri, İş-Güç Endüstri İlişkileri ve Inssan Kaynaklarl Dergisi, 9(3):1-24.

Özkaplan, N. (2013). Kadın akademisyenler: Cam tavanlar hâlâ çok kalın!. Kadın Araştırmaları Dergisi, 12(1), 1-23.

Page, Z. A. ve İnce, M. (2008). Aile İçi Şiddet Konusunda Bir Derleme, Türk Psikoloji Yazıları, 11(22): 81-94.

Strauss, A. and Corbin, J. (1998). Basics of Qualitative: Techniques and Procedures for Developing Grounded Theory. Sage Publacations. 
Şenesen, G. G. ve Pulhan, E. (2000). Kadın İstihdamı İçin Yeni Perspektifler ve Kadın İşgücüne Muhtemel Talep, Kadın Statüsü ve Sorunları Genel Müdürlügü̈, Ankara.

Şener, B. E. (2011). Kadına Yönelik Aile İçi Şiddeti Önlemede 4320 Sayılı Ailenin Korunmasına Dair Kanun ve Değerlendirme, T.C. Başbakanlık Kadının Statüsü Genel Müdürlüğü, Ankara.

TC Başbakanlık Türkiye İstatistik Kurumu. (2016). İşgücü istatistikleri, Haziran 2016, Ankara. http://Dataworldbank.org/indicator/SL.TLF.CACT.FE.ZS?end=2014\&start=1990\&view=map\&year=2 014., A.T. 20.01.2017

TC. Başbakanlık Türkiye İstatistik Kurumu. (2017). İşgücü Maliyeti ve Kazanç İstatistikleri, http://www.tuik.gov.tr/PreTablo.do?alt_id=1008, A.T.21.01.2017.

Taylor, E. S.; Letitia A. P. and David, S. (2007). Sosyal psikoloji. (A. Dönmez, Çev.). (12-14). İmge Kitabevi Yayınları, Ankara.

Uygun, Z. (2011). Örgüt Kültürünün Kadın Çalışanların Kariyer Gelişimleri Üzerine Etkisi, Yayımlanmamış Yüksek Lisans Tezi, Selçuk Üniversitesi, Sosyal Bilimler Enstitüsü Müdürlügü, Konya.

Ünal, L. I. (1991). İşgücü Piyasalarında Eğitimsel Niteliklerin Rolü. Ankara Üniversitesi Eğitim Bilimleri Fakülte Dergisi, 24(1-2):747-767.

Ünnü A. N.; Baybars, M. ve Kesken, J. (2014). Türkiye'de Kadınların Üniversiteler Bağlamında Yetki ve Karar Verme Mekanizmalarına Katılımı, Dumlupınar Üniversitesi Sosyal Bilimler Dergisi, 42:121134.

Vefikuluçay, D.; Demirel, S.; Taşkın, L. ve Eroğlu, K. (2007). Kafkas Üniversitesi son sınıf öğrencilerinin toplumsal cinsiyet rollerine ilişkin bakış açıları. Hacettepe Üniversitesi Hemşirelik Yüksekokulu Dergisi, 14 (2): 12-27.

Yamak, N. ve Topbaş, F. (2004). Kasın emeği ve cinsiyete dayalı ücret ayrımcılı̆̆ı. Atatürk Üniversitesi Iktisadi ve İdari Bilimler Dergisi, 18(3-4): 143-156.

Yılmaz S. A. ve Şaşmaz Y. O. (2012). Aile İçi Şiddete Etken Sosyo Kültürel Faktörler: Elazı̆̆ Kervancılar ilçesi Örneği. Uluslararası Katılımlı Kadına ve Çocuğa Karşı Şiddet Sempozyumu, Ankara (2):907-915.

Zaph, D. (1999), Organizational Work Group Related and Personal Causes of Mobbing/Bullying at Work, International of Manpower, 20 (1/2).

Xu, X.; Zhu, F.; O'Campo, P.; Koenig, A. M.; Mock, V. and Campbell, J. (2005). Prevalence of and risk factors for intimate partner violence in China. Am J Public Health. 95(1):78-85. 